\title{
¡ㄱㅌㄷI\&NE
}

\section{Wetting-Drying Resistance of a Lime Stabilized Soil Amended with Steel Slag and Reinforced with Fibres}

\author{
Resistencia a la humedad y al secado de un suelo estabilizadlo con call modifícado \\ con escoria de acero y reforzado con fibras
}

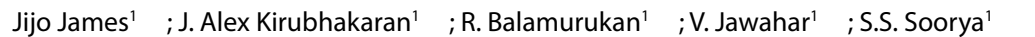

'Sri Sivasubramaniya Nadar College of Engineering , Chennai, India. jijoj@ssn.edu.in

Recibido: 10 marzo de 2020 Aceptado: 9 noviembre de 2020

\begin{abstract}
The investigation dealt with the stabilization of expansive soil with combinations of lime, steel slag and reinforced with two types of fibres, copper filaments and polypropylene fibres. The investigation began with the characterization of the soil for its geotechnical properties. The initial consumption of lime required for the modification of the soil properties was determined from the Eades and Grim pH test. Cylindrical specimens of soil with dimensions $38 \mathrm{~mm} \times 76 \mathrm{~mm}$ were cast using this lime content as a stabilizer along with varying quantities of steel slag for determination of optimum steel slag content. The pure lime stabilized soil as well as lime-steel slag modified soil specimens were reinforced with different proportions of copper filaments for determination of optimum fibre content. One dosage of polypropylene fibres was also adopted as reinforcement in specimen preparation. The optimal combinations identified were then subjected to a maximum of three cycles of wetting and drying followed by determination of unconfined compression strength (UCS). The expansive soil required a minimum of $3 \%$ lime for its modification. The optimum dosage of steel slag was identified as $\mathbf{5 \%}$ and optimum copper filament content as $1 \%$. Polypropylene content of $0.3 \%$ was also adopted as one combination. The results of the investigation revealed that lime stabilized fibre-reinforced soil with copper filaments was the most durable combination followed by polypropylene fibres. The introduction of steel slag in the
\end{abstract}

mix could not generate enough beneficial durability to the soil after three cycles of wetting and drying.

Keywords-Soil; Lime; Slag; Fibre; Strength; Durability.

Resumen- La investigación se ocupó de la estabilización del suelo expansivo con combinaciones de cal, escoria de acero y reforzado con dos tipos de fibras, filamentos de cobre y fibras de polipropileno. La investigación comenzó con la caracterización del suelo por sus propiedades geotécnicas. El consumo inicial de cal requerido para la modificación de las propiedades del suelo se determinó a partir de la prueba de pH Eades y Grim. Se moldearon muestras cilíndricas de suelo con dimensiones de $38 \mathrm{~mm} \times 76 \mathrm{~mm}$, utilizando este contenido de cal como estabilizador junto con cantidades variables de escoria de acero para la determinación del contenido óptimo de escoria de acero. El suelo estabilizado con cal pura y las muestras de suelo modificadas con escoria de acero de cal se reforzaron con diferentes proporciones de filamentos de cobre para determinar el contenido óptimo de fibra. También se adoptó una dosis de fibras de polipropileno como refuerzo en la preparación de muestras. Las combinaciones óptimas identificadas se sometieron luego a un máximo de tres ciclos de humectación y secado, seguido de la determinación de la resistencia a la compresión no confinada (UCS). EI suelo expansivo requirió un mínimo de $3 \%$ de cal para

Citar este artículo como: James J, Kirubhakaran JA, Balamurukan R, Jawahar V, Soorya SS. Wetting-Drying Resistance of a Lime Stabilized Soil Amended with Steel Slag and Reinforced with Fibres. ITECKNE, 18(1), 2021 pp. 7 - 17. DOI: https://doi.org/10.15332/iteckne.v18i1.2490 
su modificación. La dosis óptima de escoria de acero se identificó como $5 \%$ y el contenido óptimo de filamento de cobre como $1 \%$. El contenido de polipropileno del $0.3 \%$ también se adoptó como una combinación. Los resultados de la investigación revelaron que el suelo reforzado con fibra estabilizado con cal con filamentos de cobre fue la combinación más duradera seguida por las fibras de polipropileno. La introducción de escoria de acero en la mezcla no pudo generar suficiente durabilidad beneficiosa para el suelo después de tres ciclos de humectación y secado.

Palabras clave- Suelo; cal; escoria; fibra; resistencia; durabilidad.

\section{INTRODUCTION}

Expansive soils are known all over the world for their poor volume stability. Construction on such soils results in disastrous effects on the structures built over them. Lime stabilization of expansive soils has been one of the most common solutions to mitigate the dangerous effects of expansive soils. However, there are also regions wherein the subsoil is subjected to extreme conditions. These include wetting-drying, freezing-thawing, high soil acidity and alkalinity, high soil salinity, high sodic soil conditions, sulphate rich soils, and contaminated soils. In such conditions, the effectiveness of the stabilization used slowly reduces over an extended period. This may lead to a reduction in the durability of the stabilized soil. James and Pandian [1] suggest that lime stabilized soils lose their effectiveness in extreme conditions, especially in tropical climatic conditions and in cold regions. In recent times, there have been several investigations by various researchers addressing the durability of the lime stabilized soils [2-7]. Based on these investigations, the researchers reported that the beneficial effect of lime in swell control and improvement of soil properties was partially lost due to multiple cycles of wetting and drying. Literature suggests that there have been investigations using industrial solid wastes as well as a few combinations of lime and industrial solid wastes for soil stabilization [8]. Over the years, few of the researchers have attempted to improve the performance of lime stabilization by combining it with pozzolans to improve its performance under such extreme conditions. A very early study conducted by Hoover et al. [9] attempted to study the performance of fly ash-lime stabilized mixes. Kampala et al. [10] studied the effect of the addition of fly ash on the wet-dry resistance of carbide lime stabilized soil. Sabat and Nanda [11] researched the performance of marble dust modification of rice husk ash stabilized soil subjected cycles of wetting and drying. Yilmaz and Fidan [12] explored the effect of combinations of lime and perlite on the wetting-drying performance of clayey soil. Harichane et al. [13] attempted to study the effect of lime-natural pozzolana on the durability of clayey soils subjected to multiple cycles of wetting and drying. These studies found that the addition of wastes/ pozzolans to lime during stabilization resulted in improved performance during wetting and drying cycles. However, despite the early attempt of using waste pozzolans with lime, studies on the utilization of combinations of lime and solid wastes for resistance against cycles of wetting and drying are still very minimal. Other researchers have also investigated the improvement of wetting-drying resistance of soils by the inclusion of fibres. Malekzadeh and Bilsel [14] studied the effect of polypropylene fibres on the mechanical behaviour of expansive soils. They also investigated the effect of polypropylene fibre reinforcement on the swell and compressibility of expansive soils [15]. Phanikumar et al. [16] investigated the effect of wetting and drying cycles on the heave behaviour of fibre reinforced expansive soils. Greeshma and Joseph [17] included rice straw fibres into Kuttanad expansive clay to investigate its performance. Others went one step further by combining lime/cement with fibres to improve its durability performance. Prajisha and Ajitha [18] explored the performance of banana fibre reinforced lime stabilized soil subjected to cycles of wetting and drying. Anggraini et al. c considered the reinforcement benefits of nano modified coir fibre in lime treated marine clay. Sukontasukkul and Jamsawang [20] adopted metallic steel fibres for the strengthening of deep soil-cement columns. Fatahi et al. [21] adopted polypropylene and steel fibres to improve the performance of cement stabilized silty clay. Correia et al. [22] investigated the effect of stabilization of soil with a combination of cement, ground granulated blast furnace slag and steel fibres. The addition of fibres to reinforce stabilized soils provided the advantage of micro-reinforcement by the fibres in resisting crack propagation when stabilized specimens were subjected to durability conditions like wetting and drying. Each fibre type has its own advantages and disadvantages. Natural fibres are renewable and environment friendly. But there is always a question over their durability when exposed to water and require treatment to ensure increased performance. Artificial fibres like polypropylene fibres are readily available in huge quantities and durable. But, they are comparatively costly and have issues of floating in water during their mixing with soil. They also require considerable care and effort to ensure a uniform and intimate mix with the soil. Metallic fibres like steel fibres have the issue of corrosion over an extended period of time. They are however, comparatively stronger and stiffer than other fibres. Polypropylene fibres have been the most common type of fibre reinforcement considered by researchers. Other types of artificial fibres like nylon and polyester as well as natural fibres like banana and coir have also been investigated. But, there seems to be very few investigations considering metallic fibres in soil micro-reinforcement. Thus, in summary, it can be seen that researchers have attempted to improve the durability of lime stabilized soil by addition of industrial wastes/fibres. However, it was found that very few investigations have focussed on the combinations of lime, industrial wastes and fibres for improving the durability performance like the one done by Muntohar and Khasanah [23]. They examined the performance of clayey soil stabilized with lime and rice husk ash reinforced with polypropylene waste fibres subjected to cycles of wetting and drying. There still exists a great potential for identification of optimal combinations 


\section{METHODS}

The experimental methodology followed in this investigation consisted of the following stages: Collection and preparation of materials, characterization of materials, determination of initial consumption of lime (ICL), identification of optimum steel slag content, identification of optimum fibre content, preparation of specimens, simulation of wetting and drying and specimen testing. Each of the stages has been described in detail in the following subsections.

\subsection{Collection and Preparation of Materials}

The soil sample was collected from the source and transported to the laboratory. In the laboratory, it was crushed and pulverized into smaller fractions using a hand rammer. It was then sieved through various sieves as per requirement for various tests done following the codes of BIS. The lime was used as supplied by the manufacturer. Steel slag was crushed and sieved through 75-micron sieve and the fine powder passing through the sieve was used in the study. Copper filaments were cut to an aspect ratio of 77 from long wires. Polypropylene fibres were used as supplied by the retailer.

\subsection{Characterization of Materials}

The soil obtained for the investigation was subjected to various geotechnical properties as per different codes of BIS. The various properties evaluated include liquid and plastic limit [25], shrinkage limit [26], specific gravity [27], grain size distribution [28], compaction [29], unconfined compression strength (UCS) [30] and free swell index [31]. The soil was then classified based on the guidelines of BIS code [32]. Steel slag was subjected to a specific gravity test following the same procedure that was adopted for soil.

\subsection{Determination of Initial Consumption of Lime}

Based on the existing literature, for the soil under investigation, the ICL value was determined from the Eades and Grim pH test [33] based on the ASTM code D6276 [34].

\subsection{Identification of Optimum Steel Slag Content}

To determine the optimum steel slag content of the given soil sample, UCS tests were performed on the soil samples stabilized with lime (ICL). All UCS samples for determination of optimum steel slag content were compacted to MDD and OMC of the stabilized soil obtained from mini compaction tests [29] done based on the BIS code [35] procedure for stabilized soil. A calculated quantity of dry soil was weighed out. To this, minimum lime content and one trial content of steel slag by weight of dry soil was added in dry condition and manually mixed to achieve a uniform dry mix. The quantities of lime, steel slag and soil were calculated such that the final weight of the dry mix was equal to the weight required for achieving the dry density of the UCS sample, which in the present case was fixed as the MDD of the lime stabilized soil. To this uniform dry mix, water content equal to the OMC of the stabilized soil was sprinkled in stages, combined with manual mixing until a uniform wet mix was achieved. This mix was packed into the constant volume split mould of internal diameter, $38 \mathrm{~mm}$ and height, $76 \mathrm{~mm}$, and compacted by static loading. After the samples were cast, they were immediately de-moulded and air-cured in sealed polythene covers to prevent loss of moisture. Three specimens were cast for each combination of steel slag adopted for stabilization. The steel slag content was varied from $5 \%$ to $20 \%$ in increments of $5 \%$ by weight of dry soil for determining the optimum content. The samples were cured for 3 days before they were tested. James and Pandian [36] had adopted a curing period of 2 days for identifying the optimum lime content in their investigation. The combination that gave the maximum strength/minimum loss in strength was adopted as the optimum content.

\subsection{Identification of Optimum Fibres Content}

The optimum fibre content was also determined using the same procedure as adopted for the determination of optimum steel slag content. The soil specimens of $38 \mathrm{~mm}$ diameter and $76 \mathrm{~mm}$ height were prepared by mixing the minimum lime content and optimum steel slag content. In this mix, the fibre content was varied from $0.5 \%$ to $2 \%$ in increments of $0.5 \%$. Three samples were prepared for each combination and cured for 3 days. The combination that produced the maximum strength/minimum loss in strength was considered as the optimum fibre content. Polypropylene fibres being one of the most commonly adopted fibres, its optimum fibre content was adopted from the literature [37], for comparison with the performance of copper filaments.

\subsection{Preparation of Test Specimens}

The UCS samples were prepared in a constant volume split mould of dimensions $38 \mathrm{~mm} \times 76 \mathrm{~mm}$, de-moulded immediately and placed inside a sealable polythene cover for curing. Three samples were prepared for testing each of the combinations. Figure 2 shows the preparation and testing of a UCS sample. Calculated quantities of soil, lime, steel slag and filaments/fibres were packed in sealed polythene covers for sample preparation. A steel UCS split mould of height $76 \mathrm{~mm}$ and internal diameter $38 \mathrm{~mm}$ was prepared by lubricating its interior with oil. The materials were emptied on to a mixing pan and mixed in dry state manually. The required quantity of water was sprinkled on to it and mixed thoroughly to obtain a uniform wet mix. The mixture was then packed into a steel UCS mould in layers with gentle compaction provided by a compaction plug. This was repeated until the entire wet mix was packed into the split mould. The mould was then plugged at both ends using the end plugs. It was loaded on to a universal sample compacter cum extruder and compacted by applying static pressure. Care was taken to introduce the layers of wet mix alternatively from either end of the split mould and compacted from the corresponding end to ensure 
uniform compaction of the prepared UCS sample [38]. The sample was then ejected after opening the split mould and applying gentle pressure using the compaction plug. The samples were cured at room temperature of $30^{\circ} \mathrm{C}+/-2^{\circ} \mathrm{C}$ in sealed polythene covers for 14 days. Fig. 2 shows the preparation of samples for the investigation.

Fig. 2 PREPARATION OF SPECIMENS

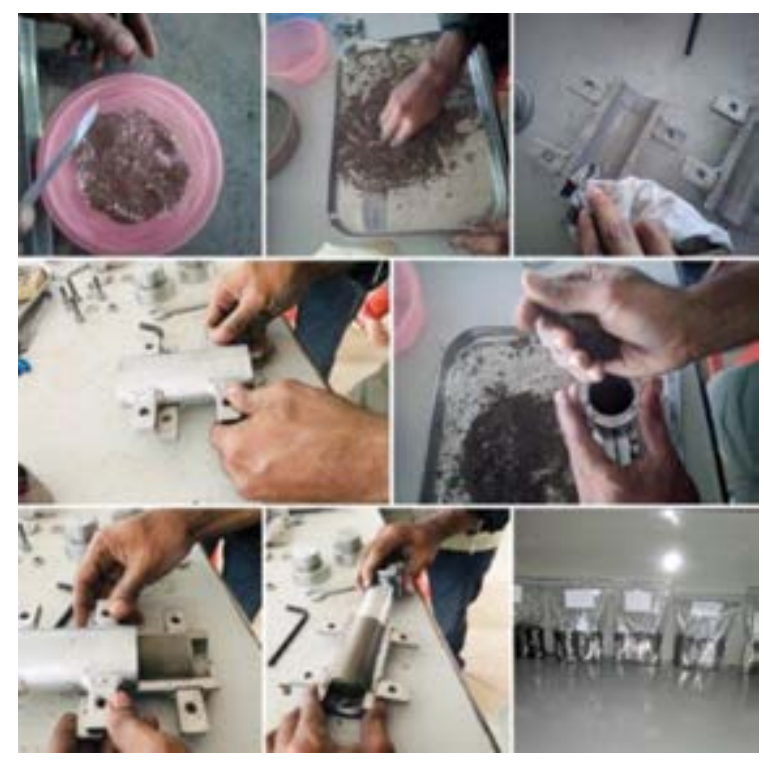

Source: The authors

\subsection{Simulation of Wetting and Drying}

The samples were subjected to alternate cycles of wetting and drying by simulating the conditions of wetting and drying. A wet-dry cycle consisted of two phases: A 24 hours wetting phase wherein the samples were covered by soaking wet cotton and a 24 hours drying phase at open-air room conditions. All specimens were subjected to 1, 2 and 3 cycles of wetting and drying after they were cured for 14 days. Various researchers have adopted a different number of cycles for their work. Phanikumar et al. [16] adopted three cycles of wetting and drying whereas Muntohar and Khasanah [23] adopted four cycles. Anggraini et al. [19] adopted five cycles of wetting and drying. Yilmaz and Fidan [12] had adopted 12 cycles of wetting and drying in their investigation.

\subsection{Specimen Testing}

After the end of the set period of curing and cycles of wetting and drying, the samples were loaded axially until failure in UCS loading frame of $50 \mathrm{kN}$ capacity. The rate of strain adopted for the test was $0.625 \mathrm{~mm} / \mathrm{min}$. The various shortlisted combinations that were evaluated for the wetting and drying resistance performance is shown in Table II.

\section{RESULTS AND DISCUSSION}

An expansive soil was stabilized using a combination of lime, steel slag and fibres for improving its strength. It was then subjected to different cycles of wetting and drying to study its durability performance. The results of the investigation are discussed in the following subsections.

\subsection{Optimization of Lime, Steel Slag and Fibre Content}

The ICL is the minimum lime content required to raise the $\mathrm{pH}$ to 12.4 . In highly alkaline conditions, the soil silica and alumina dissolve and react with the calcium from lime forming stabilization reaction products. Thus, high $\mathrm{pH}$ value is essential for stabilization reactions to proceed. The $\mathrm{ICL}$ was determined using the Eades and Grim pH test [33] based on ASTM D6276 [34]. The ICL for the soil under investigation was found to be $3 \%$ as shown in Fig. 3 .

Fig. 3. DETERMINATION OF INITIAL CONSUMPTION OF LIME

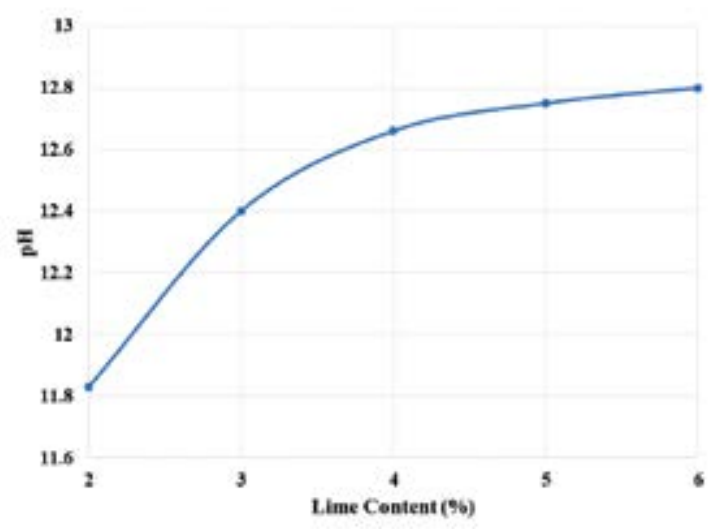

Source: The authors

Table II.

STABILIZER AND FIBRE CONTENT COMBINATIONS FOR WET-DRY TESTS

\begin{tabular}{|c|c|c|c|c|}
\hline Lime (\%) & Steel Slag (\%) & $\begin{array}{c}\text { Copper Filament } \\
(\%)\end{array}$ & $\begin{array}{c}\text { Polypropylene Fibres } \\
(\%)\end{array}$ & Designation \\
\hline 3 & 0 & 0 & 0 & S3L \\
\hline 3 & 0 & 1 & 0 & S3L1CF \\
\hline 3 & 0 & 0 & 0.3 & S3L0.3PF \\
\hline 3 & 5 & 1 & 0 & S3L5SS1CF \\
\hline 3 & 5 & 0 & 0.3 & S3L5SS0.3PF \\
\hline
\end{tabular}

Source: The authors 
of lime, wastes and fibres. This investigation attempted to address this gap in literature by considering a combination of lime, steel slag and copper filaments as well as polypropylene fibres in the stabilization and durability performance of an expansive soil subjected to alternate cycles of wetting and drying.

\section{MATERIALS USED}

The various materials used in the present investigation were the virgin expansive soil, high-quality industrial-grade lime, steel slag, copper filaments and polypropylene fibres. Lime was used as the primary binder, whereas steel slag was used as an auxiliary additive. The copper filaments and polypropylene fibres were used as random micro reinforcement.

The virgin expansive soil adopted in this investigation was collected from the banks of Thaiyur lake, near Kalavakkam, Tamil Nadu, India. The soil sample was prepared following the Bureau of Indian Standards (BIS) code [24]. The soil sample was subjected to various geotechnical tests in the laboratory according to the various codes of BIS. The properties of soil are tabulated in Table I. High-quality industrial-grade hydrated lime was sourced from M/s. Shiyal Chemicals, Chennai. No specific preparation methods were adopted for lime, which was used as supplied in the commercial packets. Steel slag is a by-product resulting from the manufacturing process of steel. It is obtained during the separation of molten steel from the impurities in the furnace in a liquid state. It is a complex solution of silicates and oxides, which solidifies into steel slag on cooling. Steel slag was obtained from Jindal Steel Works, Salem. Its specific gravity was found to be 2.67 . The steel slag was prepared by crushing and sieving it through 75-micron sieve. The finer fraction which passed through the 75-micron sieve was used in the investigation. Fig. 1 shows the various materials after preparation.

Copper filaments were adopted as fibre reinforcement as a replacement for steel fibres adopted by certain investigators in soil stabilization. Copper was bought as wires from a motor winding shop. It had a diameter of $0.14 \mathrm{~mm}$. It was cut into filaments of $10 \mathrm{~mm}$ length based on which the aspect ratio was approximately 77 . Polypropylene fi- bres were used in the investigation to obtain a comparative performance evaluation for copper filament reinforced soil. The polypropylene fibres were purchased from a commercial retailer in Chennai. It had a length of $12 \mathrm{~mm}$ and a diameter of $0.025 \mathrm{~mm}$, based on which its aspect ratio came out to be 480 .

Fig. 1. PREPARED VIRGIN EXPANSIVE SOIL AND STEEL SLAG
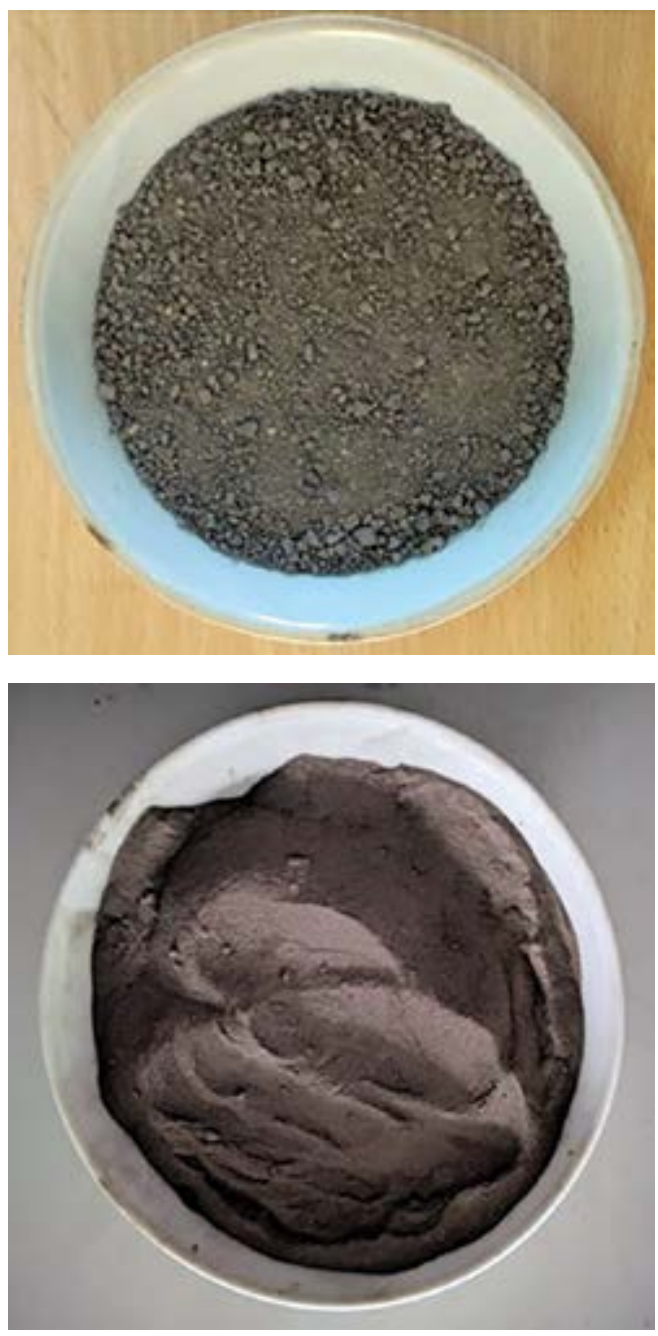

Source: The authors

Table I.

PROPERTIES OF VIRGIN SOIL

\begin{tabular}{|l|l|l|c|}
\hline \multicolumn{1}{|c|}{ Property } & \multicolumn{1}{c|}{ Value } & \multicolumn{1}{c|}{ Property } \\
\hline Liquid Limit & $70.0 \%$ & Maximum Dry Density (MDD) & $13.4 \mathrm{kN} / \mathrm{m} 3$ \\
\hline Plastic Limit & $22.8 \%$ & Optimum Moisture Content (OMC) & $28.4 \%$ \\
\hline Plasticity Index & $47.2 \%$ & Unconfined Compression Strength (UCS) & $103.1 \mathrm{kPa}$ \\
\hline Shrinkage Limit & $9.0 \%$ & Free Swell Index & $120 \%$ \\
\hline Specific Gravity & 2.68 & Classification & $\mathrm{CH}$ \\
\hline
\end{tabular}

Source: The authors 
The optimization of steel slag and copper filaments contents was also done by conducting UCS tests. Fig. 4 and Fig. 5 show the results of the UCS tests for determination of optimal content of steel slag and copper filaments. It can be seen that increase in steel slag content results in a reduction of the strength of the specimens. Therefore, the steel slag content with the minimum loss in strength was considered to be the optimal dosage. The incorporation of steel slag in the stabilization process is for the utilization of solid waste for effective waste management.

The optimization of copper filament content for fibre reinforcement of the specimens was performed using a similar procedure. The soil stabilized with $3 \%$ lime was amended with copper filaments starting from $0.5 \%$ in increments of $0.5 \%$ up to $2 \%$, Fig. 5 shows the variation in the strength of the specimens amended with different proportions of copper filaments by the weight of the soil. From the graph, it can be seen that there is an initial reduction in strength of the stabilized specimen reinforced with $0.5 \%$ copper filaments. Further increase in the filament content to $1 \%$ leads to a rise in strength of the specimen. However, no further variations in the strengths were noticed for higher contents of copper filaments. Hence, it was concluded that a minimum of $1 \%$ copper filaments was the optimal dosage that resulted in the least loss in strength, Fig. 5 also shows the optimal copper filament content for $3 \%$ lime and $5 \%$ steel slag stabilized soil. It can be seen that the optimal copper filament content for steel slag amended lime stabilized soil was also $1 \%$. Thus, irrespective of the steel slag amendment, the optimum copper filament content for reinforcing the soil came out to be 1\%, Fatahi et al. [21] identified $10 \%$ of steel fibre content developed the maximum strength for cement-treated silty clay soil. Sukontasukkul and Jamsawang [20] found that $1 \%$ of steel fibres resulted in the maximum flexural strength of fibre reinforced deep soil-cement column. This was irrespective of long or short fibre steel adopted in the study. The optimal dosage of polypropylene fibres (0.3\%) was adopted from the work done by Jiang et al. [37], who had done extensive work on optimizing the fibre content based on aspect ratio and dosage. Muntohar and Khasanah [23] had adopted a similar polypropylene waste fibre content of $0.4 \%$.

\subsection{Effect of Stabilization and Reinforcement on the Strength}

Figure 6 , shows the effect of the amendment of $3 \%$ lime with the various optimal doses of additives, viz. $5 \%$ steel slag, $1 \%$ CF and $0.3 \%$ polypropylene fibres in different combinations. It can be seen that all the optimal amendments have resulted only in a positive gain in strength due to the modification. The polypropylene fibre modification developed the least gain in strength when compared to all combinations. On the other hand, the samples reinforced with copper filaments produced the maximum gain in strength under normal conditions. The result was in contrast to the results obtained by Fatahi et al. [21] and Sukontasukkul and
Jamsawang [20]. Both the studies reported polypropylene fibres developing better strength when compared to metallic steel fibres. This may be because the polypropylene fibre dosage for the soil under investigation was not identified but rather chosen from literature for comparison. Introduction of steel slag resulted in a slight reduction in strength in the case of copper filament reinforcement whereas it resulted in an increase in strength in the case of polypropylene reinforced lime stabilized soil. Thus, different reinforcement materials produce different degrees of improvement and modification of lime stabilization. The same can also be said for steel slag amendment of lime stabilization.

\section{Fig. 4. DETERMINATION OF OPTIMUM STEEL SLAG CONTENT}

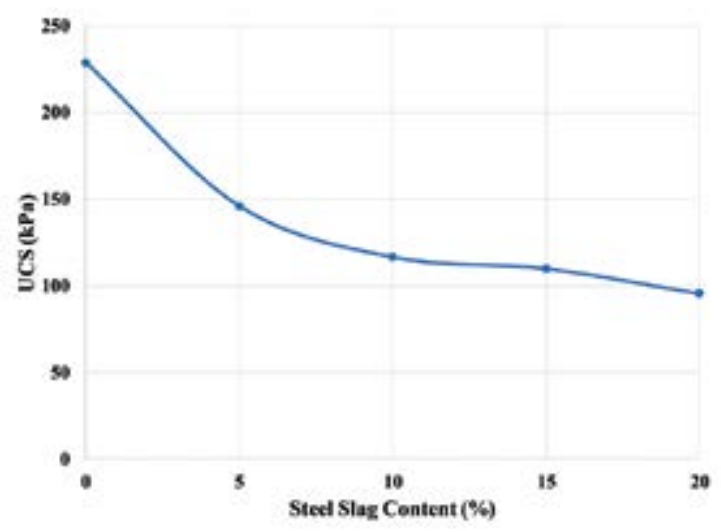

Source: The authors

Fig. 5. DETERMINATION OF OPTIMUM COPPER FILAMENT CONTENT

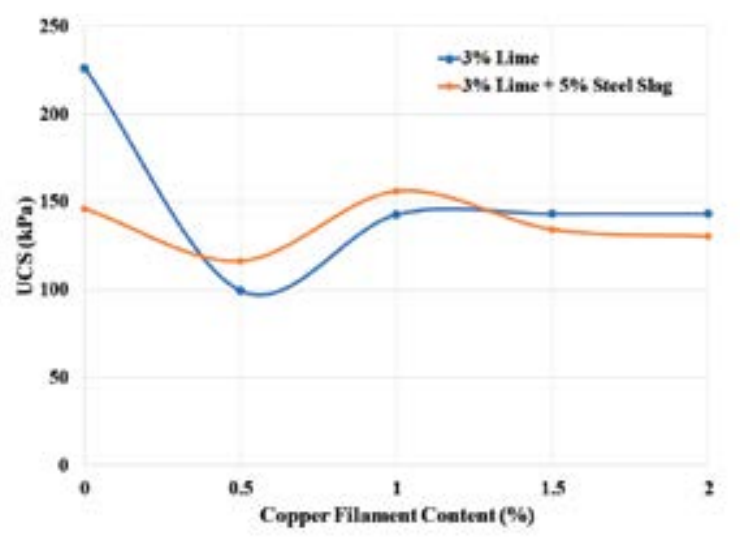

Source: The authors

\subsection{Effect of Wetting and Drying on the Strength of Stabilized Soil}

The effect of wetting and drying cycles on the compressive strength of the various specimen combinations were studied by conducting UCS tests on the samples after subjecting them to multiple cycles of wetting and drying. 
Fig. 6. EFFECT OF OPTIMAL AMENDMENTS ON LIME STABILIZATION

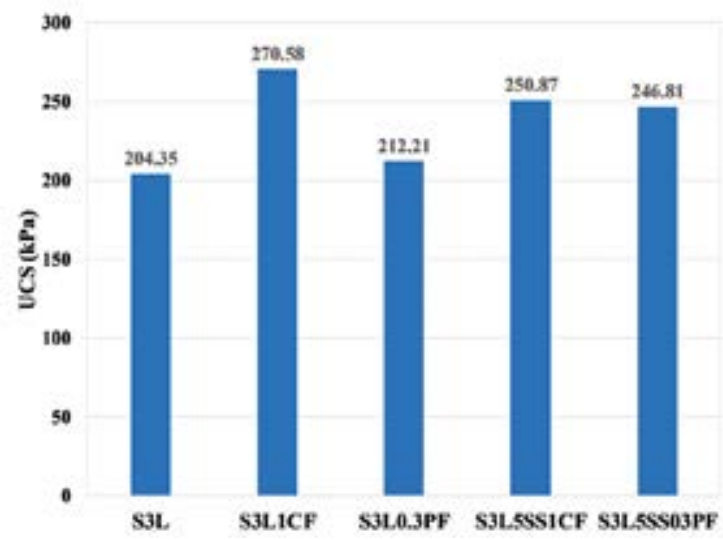

Source: The authors

\subsubsection{Effect of Fibres on Durability of Lime Stabilized Soil}

Figure 7, shows the effect of fibre reinforcement on the wetting and drying resistance of pure lime stabilized soil. For comparison of performance, the wetting and drying resistance of pure lime stabilized soil without fibre reinforcement (control) has also been shown in the figure. The strength of the lime stabilized soil increases from 204.35 $\mathrm{kPa}$ to $329.31 \mathrm{kPa}$ after the first cycle of wetting and drying. The increase in strength of the stabilized soil after the first cycle of wetting and drying may be indicative of a deficiency in water content during the moulding process. This deficiency may have been fulfilled during the first immersion cycle leading to an increase in the strength. The lime stabilized soil loses strength on a further increase in the number of wetting and drying cycles. The strength of the stabilized soil decreases to $161.15 \mathrm{kPa}$ for three cycles of wetting and drying. Anggraini et al. [19] also reported a reduction in the strength of lime treated marine clay with an increase in cycles of wetting and drying. In the case of copper filament reinforced lime stabilized soil as well, there is an increase in the strength of the stabilized soil after the first cycle of wetting and drying. Again, this may be indicative of a deficiency in water content, fulfilled by the wetting stage of the cycle resulting in improved strength. The strength of the copper filament reinforced lime stabilized soil increases from $270.58 \mathrm{kPa}$ to $325.82 \mathrm{kPa}$ after the first cycle of wetting and drying. On the subsequent increase in the number of cycles, there is a reduction in the strength of the specimens. However, even after three cycles of wetting and drying, the strength of the specimens has not lowered below that of the control specimens. The reduction in strength seems to have stabilized after the second cycle with no big difference in the strength of the specimens subjected to two and three cycles of wetting and drying. In general, it can be seen that the strength of the specimens subjected to cycles of wetting and drying is higher than the control specimens. This indicates a better resistance to wetting and drying due to the reinforcement of the specimens with copper filaments.
In the figure 7, is clear that the trends of polypropylene reinforced lime stabilized soil are similar to that of pure lime stabilized soil. The major difference is an increase in strength up to two cycles of wetting and drying beyond which there is a reduction in strength of the specimens. Muntohar and Khasanah [23] reported an increase in the strength of the specimens stabilized with a combination of lime-rice husk ash-polypropylene fibres up to three cycles of wetting drying. Anggraini et al. [19] reported an increase in the strength of coir fibre reinforced lime treated marine clay up to five cycles of wetting and drying. Muntohar and Khasanah [23] also report that samples prepared with moisture content lesser than optimum (dry side of optimum) have a higher strength development. In the present study as well, polypropylene fibre reinforced lime-steel slag stabilized soil specimens had an increase in the strength for more than one cycle of wetting and drying. The presence of the fibres may have resulted in improved hydration of the soil specimens while resisting the spread of cracking. Anggraini et al. [19] state that the presence of the fibres increased the number of wetting cycles by which sufficient moisture for hydration was supplied, resulting in improved strength of the specimens. Muntohar and Khasanah [23] attribute the increase in strength with wetting and drying cycles to two reasons. First, the increase in the duration of chemical reactions during wetting and drying cycles and second, the increase in the quantum of cementitious compounds during wetting and drying cycles.

Fig. 7. EFFECT OF WETTING AND DRYING CYCLES ON FIBRE REINFORCED LIME STABILIZED SOIL

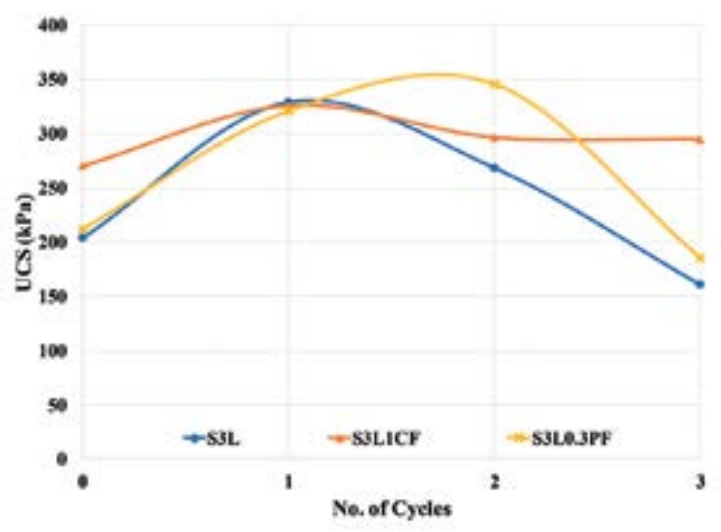

Source: The authors

\subsubsection{Effect of Fibres and Steel Slag on Durability of Lime Stabilized Soil}

The effect of fibre reinforcement was also studied on lime stabilized soil modified with optimal steel slag content. The procedure adopted was the same as for fibre reinforced pure lime stabilized soil, Fig. 7 shows the effect of wetting and drying cycles on lime-steel slag stabilized soil. The inclusion of steel slag in the stabilization process results in a slight modification in the response of the stabilized specimens subjected to wetting and drying cycles. 
It can be seen that the lime-steel slag stabilized specimens modified with $1 \%$ copper filaments result in better resistance to wetting and drying up to two cycles. Further increase in the cycles results in a drastic reduction in strength of the stabilized specimen. Thus, the inclusion of steel slag in the stabilization process results in strength benefits only up to two cycles of wetting and drying.

Figure 8 also shows the effect of wetting and drying on the $0.3 \%$ polypropylene reinforced lime-steel slag stabilized soil. The inclusion of steel slag in the stabilization process results in a similar trend as for copper filament reinforced lime-steel slag stabilized soil. There is a significant benefit in the resistance to wetting and drying cycles until two cycles. Beyond two cycles, there is a drastic reduction in the strength of the stabilized soil. Thus, in both the cases of copper filaments and polypropylene fibres, the beneficial effect of steel slag was obtained only up to two cycles of wetting and drying. The introduction of steel slag as a pozzolan in the mix could not extend the resistance to a higher number of wetting and drying cycles. Hasan et al. [39] found that the introduction of bagasse ash in lime stabilization resulted in the stabilized composite becoming more durable when subjected to ten cycles of wetting and drying. A similar objective attempted with steel slag in the present investigation could not be achieved.

\section{Fig. 8. EFFECT OF WETTING AND DRYING CYCLES ON FIBRE REINFORCED} LIME STABILIZED SOIL AMENDED WITH STEEL SLAG

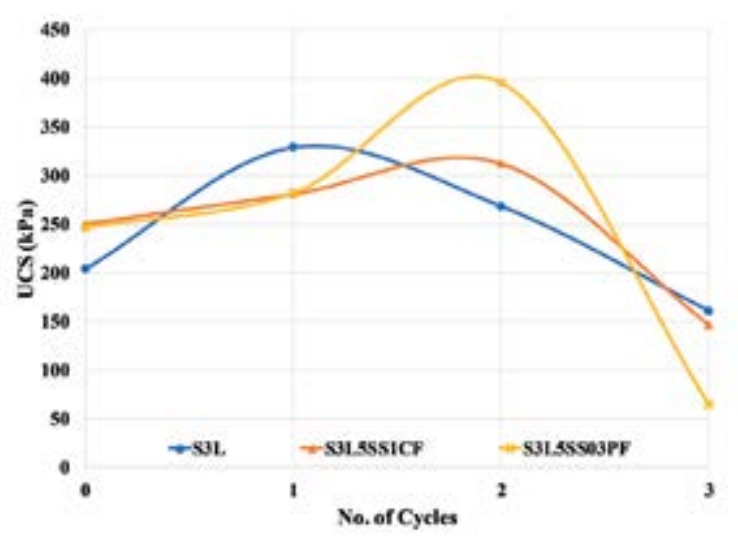

Source: The authors

\subsubsection{A Comparative Discussion}

To understand the extent of strength development of fibre reinforced lime stabilized soil subjected to alternate cycles of wetting and drying, a comparison with similar studies was attempted. Two studies were identified for comparison with the present study viz. the work done by Anggraini et al. [19] and Muntohar and Khasanah [23]. These two were selected because the former adopted a combination of lime and fibres and the latter adopted a combination of lime, waste and fibres. However, there are inherent limitations of such a comparison. At the outset, the obvious differences in the type of soil, type of binder/stabilizer and its content, type of auxiliary additive and its content and lastly, the type of fibre and its contents do not allow a direct one to one comparison. Therefore, this comparison is a superficial one. Secondly, both the studies subjected these combinations to multiple cycles of wetting and drying. But, the comparison was limited to only 3 cycles of wetting and drying adopted in the present study. Lastly, other studies with a combination of lime and metallic fibres subjected to wetting and drying could not be found and hence, were not included. Table III gives a brief overview of the combinations used in the investigations. The combinations shown in the table have been modified according to the same naming convention used in the present study. Only the optimal dosage combinations from the present study have been shown in Table III.

Table III.

OVERVIEW OF STABILIZER AND FIBRE COMBINATIONS OF THE TWO INVESTIGATIONS

\begin{tabular}{|c|c|c|c|}
\hline Detail & $\begin{array}{l}\text { Anggraini } \\
\text { et al. [19] }\end{array}$ & $\begin{array}{l}\text { Muntohar and } \\
\text { Khasanah [23] }\end{array}$ & $\begin{array}{l}\text { Present } \\
\text { Study }\end{array}$ \\
\hline $\begin{array}{l}\text { Stabilizer } \\
\text { Type }\end{array}$ & Lime & Lime & Lime \\
\hline $\begin{array}{l}\text { Stabilizer } \\
\text { Content }\end{array}$ & $5 \%$ & $17 \%$ & $3 \%$ \\
\hline Fibre Type & Coir Fibre & $\begin{array}{l}\text { Polypropylene } \\
\text { Waste Fibre }\end{array}$ & $\begin{array}{l}\text { Copper } \\
\text { Filaments } \\
\text { Polypropylene } \\
\text { Fibres }\end{array}$ \\
\hline Fibre Content & $1 \%$ & $0.4 \%$ & $\begin{array}{l}1 \% \text { (CF); } 0.3 \% \\
\quad(\mathrm{PF})\end{array}$ \\
\hline $\begin{array}{l}\text { Auxiliary } \\
\text { Additive }\end{array}$ & - & Rice Husk Ash & Steel Slag \\
\hline $\begin{array}{l}\text { Auxiliary } \\
\text { Additive } \\
\text { Content }\end{array}$ & - & $17 \%$ & $5 \%$ \\
\hline $\begin{array}{l}\text { Combina- } \\
\text { tions }\end{array}$ & $\begin{array}{l}\text { S5L1F* } \\
\text { S5L1FF* } \\
\text { S5L1AF* }\end{array}$ & S17L17RHA0.4PW & $\begin{array}{c}\text { S3L1CF } \\
\text { S3L0.3PF } \\
\text { S3L5SS1CF } \\
\text { S35SS0.3PF }\end{array}$ \\
\hline
\end{tabular}

$\mathrm{F}$ - Natural coir fibre, $\mathrm{AF}-\mathrm{Al}(\mathrm{OH})_{3}$ modified coir fibre, $\mathrm{FF}-\mathrm{Fe}(\mathrm{OH})_{3}$ modified coir fibre.

Source: The authors

Figure 9 shows a graph between the residual strength index (RSI) and no. of cycles. RSI may be defined as the ratio of the UCS of the samples subjected to wetting and drying cycles to that of the control samples (no wetting and drying) [40]. The same was also adopted by Anggraini et al. [19] as well as Muntohar and Khasanah [23]. Figure 9 represents the data under two categories. The curves for fibre reinforced lime stabilized soil is represented by solid lines and the curves for fibre reinforced, waste amended 
lime stabilized soil is represented by dotted lines. At the outset, it can be seen that RSI curves of Anggraini et al. [19] are different from that of the present study. S5L1F and S5L1FF are very similar to each other in terms of wet-dry resistance represented by the RSI curves. S5L1AF differentiates itself after the first cycle of wetting and drying and shows improved resistance compared to the other two. S3L1CF of the present study is different from them in the fact that it shows very good wet-dry resistance for the first cycle but that resistance reduces thereafter. But all these combinations lie within the RSI range of 1 to 1.2. The combination S3L0.3PF of the present study, however, shows a vastly different wet-dry resistance as seen from its RSI curve. Its RSI goes as high as 1.63 at cycle two and then drastically drops to 0.87 . Comparing the work of Muntohar and Khasanah [23] and the present study, there is a vast difference between their corresponding RSI curves. The wet-dry resistance of the former shows a steady improvement with the number of cycles (considered up to three), with RSI value up to 2.81. In comparison, both the combinations in the present study show improved wetdry resistance only up to two cycles of wetting and drying. This may be due to a significantly high lime content adopted by Muntohar and Khasanah [23], in their investigation compared to the present study. Secondly, the difference in auxiliary additives and their contents in both investigations could have also played a significant role.

Fig. 9. COMPARISON OF PRESENT STUDY WITH PREVIOUS INVESTIGATIONS

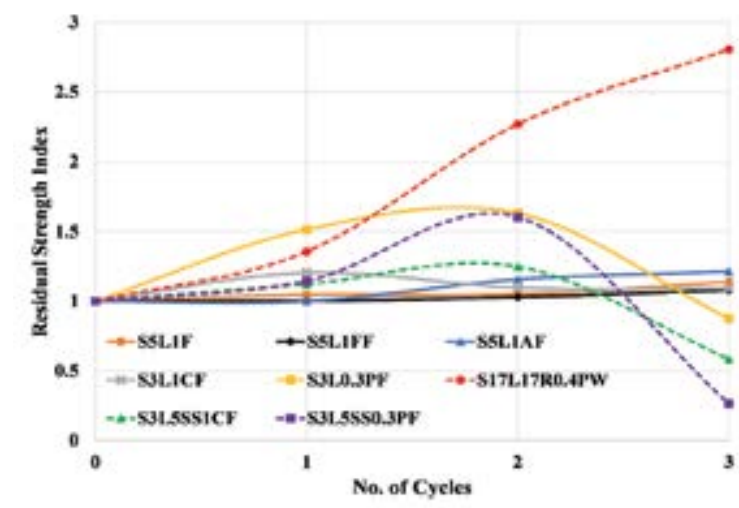

Source: The authors

\subsubsection{Percentage Strength Change Analysis}

To better understand the effect of wetting and drying on the strength of the stabilized soil samples, a percentage strength change analysis was performed. This analysis was performed from two perspectives. The first perspective was the change in strength with the number of cycles of wetting and drying. The second perspective was the strength change from that of pure lime stabilized soil for corresponding cycles of wetting and drying, Fig. 10 shows the strength change with the number of cycles of wetting and drying. It can be seen that all the combinations, gain strength after the first cycle of wetting and drying when compared to the control specimens. However, the com- binations S3L and S3L0.3PF gave the maximum strength gain of $61 \%$ and $51 \%$ respectively. For the second cycle as well all the combinations produced positive strength gain. But, the combinations of polypropylene reinforced stabilized soil (S3L0.3PF and S3L5SS0.3PF) produced the maximum strength gain of $63 \%$ and $60 \%$ respectively. After three cycles of wetting and drying, all the combinations resulted in a loss in strength barring the combination reinforced with copper filaments (S3L1CF). It still had a strength of around $9 \%$ higher than the control specimens, though marginally lesser than the $9.7 \%$ gain achieved after the second cycle of wetting and drying. Thus, it can be seen that copper filament reinforced lime stabilized soil (S3L1CF) was the most durable of all the stabilized soil combinations. Figure 11 shows the percentage strength change from pure lime stabilized soil for corresponding cycles of wetting and drying.

Fig. 10. PERCENTAGE STRENGTH CHANGE WITH NO. OF CYCLES OF WETTING AND DRYING

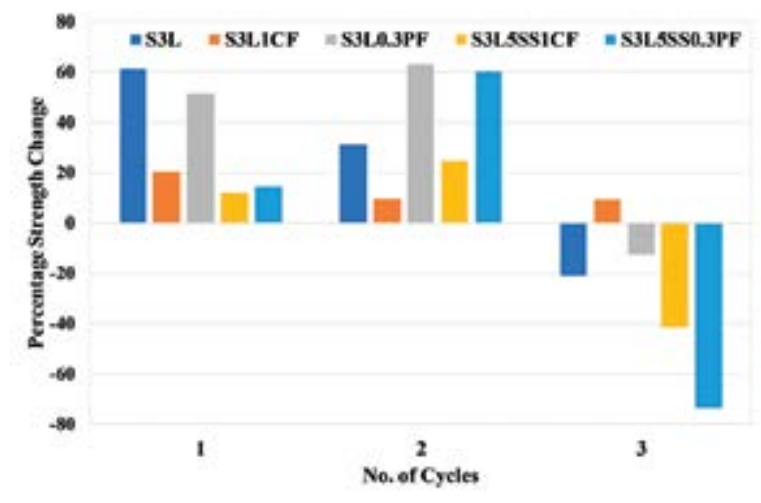

Source: The authors

Fig. 11. PERCENTAGE STRENGTH CHANGE FROM THAT OF PURE LIME STABILIZED SOIL

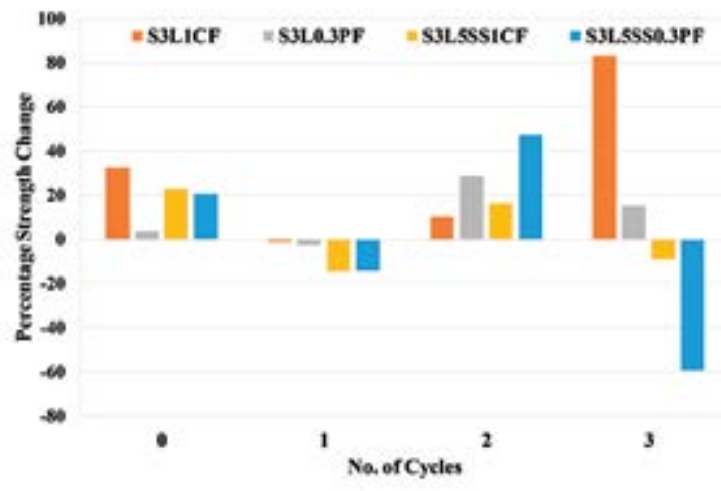

Source: The authors

It can be seen from the figure that all the combinations have given positive strength benefits when compared to the pure lime stabilized soil, when not subjected to wetting and drying cycles ( 0 Cycle). After the first cycle of wetting and drying, pure lime stabilized soil was better than all the 
combinations as there was a strength loss when compared to lime stabilized soil. But, copper filament (S3L1CF) and polypropylene fibre (S3L0.3PF) reinforced lime stabilized soil specimens were more durable compared to the steel slag amended combinations. Their loss in strengths were around $1 \%$ and $2.5 \%$ respectively. After two cycles of wetting and drying, all the combinations were better than pure lime stabilized soil. However, in this case, the polypropylene fibre reinforced combinations (S3L0.3PF and S3L5SS0.3PF) were better than pure lime stabilized soil (by $29 \%$ and $47 \%$ respectively). After three cycles of wetting and drying, it is evident that the steel slag amendment did not perform as expected, losing strength. But, on the other hand, the fibre reinforcement of lime stabilized soil resulted in good resistance to wetting-drying. The copper filament reinforced specimen (S3L1CF) and polypropylene fibre reinforced specimen (S3L0.3PF) performed $83 \%$ and $15 \%$ better than the pure lime stabilized combination (S3L), respectively. Thus, fibre reinforced lime stabilized soil performed better than fibre reinforced lime-steel slag stabilized soil, under conditions of wetting and drying. The choice of including steel slag in the stabilization can be decided based on the extent of wet-dry cycles and the location of stabilization. However, extensive studies with a greater number of wetdry cycles need to be conducted before an effective combination can be suggested for such field conditions.

\section{CONCLUSION}

The investigation involved studying the resistance of various combinations of lime, fibres and steel slag stabilized soil to alternate wet-dry cycles. Steel slag was adopted as the auxiliary additive whereas copper filaments and polypropylene fibres were used as reinforcement. The UCS of the specimens exposed to 1, 2 and 3 cycles of wetting and drying was evaluated to study the resistance to the loss in strength against control specimens. Based on the experimental investigations carried out on various combinations of lime, steel slag and fibres, the following points can be concluded.

The soil under investigation was found to be an expansive soil, classified as high plastic clay. This soil required a minimum of $3 \%$ of lime for modification of its properties. The optimal steel slag content was found to be $5 \%$. The optimal dosage of copper filaments required for maximum strength gain/minimum strength loss was found to be $1 \%$. This $1 \%$ filament content was found to be the optimal dosage irrespective of whether the soil was stabilized using lime or combinations of lime and steel slag.

All combinations of additives and fibres identified to be optimal dosages resulted in UCS higher than pure lime stabilized soil. This indicates that the introduction of steel slag as an auxiliary additive in combination with fibre reinforcement improves lime stabilization. Thus, steel slag can be effectively used in soil stabilization applications, but definitely along with fibre reinforcement.
Irrespective of combinations, all specimens investigated increased in strength after wetting and drying, which may be indicative of a water deficiency in the specimens. It can be suggested that for soils subjected to wetting and drying cycles, stabilization on the dry of optimum water content can prove to be beneficial. However, more detailed investigations need to conducted to confirm the veracity of the inference.

Introduction of auxiliary additive and fibre reinforcement resulted in improved resistance to the loss in strength when compared to pure lime stabilized soil, irrespective of the combination of additive and fibre adopted. However, the beneficial effect of the additive could be seen only till two cycles of wetting and drying. The fibre reinforcement of lime stabilized soil resulted in good resistance to wetting and drying cycles even up to three cycles. Thus, the choice of introducing an auxiliary additive like steel slag can be decided based upon the expected severity of the cyclic conditions of wetting and drying.

Based on the investigation, it can finally be concluded that copper filament reinforcement of lime stabilized soil was found to be more effective in resisting wetting and drying cycles. This can open up an avenue for potential reuse of waste copper filaments from old wiring as soil reinforcement. To conclude, waste copper filaments can be effectively used in soil stabilization activities, especially under conditions of wetting and drying.

Future investigations are needed with a higher number of wetting and drying cycles for identifying an effective and durable combination of stabilizers and fibres for resisting extreme field conditions.

\section{REFERENCES}

[1] J. James and P.K. Pandian, "Soil Stabilization as an Avenue for Reuse of Solid Wastes : A Review," Acta Tech. Napocensis Civ. Eng. Arch. 58(1):50-76, 2015.

[2] Y. Guney, D. Sari, M. Cetin and M. Tuncan, "Impact of cyclic wetting-drying on swelling behavior of limestabilized soil," Build. Environ 42(2):681-688, 2007, DOl:https://doi.org/10.1016/j.buildenv.2005.10.035

[3] G.Stoltz, O.Cuisinier and F.Masrouri, “Weathering of a lime-treated clayey soil by drying and wetting cycles," Eng. Geol. 181:281-289, 2014, DOI:https://doi.org/10.1016/j.enggeo.2014.08.013

[4] O. Cuisinier, G. Stoltz and F. Masrouri, “Long Term Behaviour of Lime-Treated Clayey Soil Exposed to Successive Drying and Wetting," Geo-Congress 2014 Technical Papers, ASCE, Atlanta, Georgia, USA: 4146-4155, 2014.

[5] A. Aldaood, M. Bouasker and M. Al-Mukhtar, "Impact of wettingdrying cycles on the microstructure and mechanical properties of lime-stabilized gypseous soils," Eng. Geol. 174:11-21, 2014, DOI:https://doi.org/10.1016/j.enggeo.2014.03.002

[6] A.M. Tang, M.N. Vu and Y.J. Cui, "Effects of the maximum soil aggregates size and cyclic wetting-drying on the stiffness of a lime-treated clayey soil," Geotechnique 61(5):421-429, 2011, DOI:https://doi.org/10.1680/geot.SIP11.005 
[7] S.A.A. Khattab, M. Al-Mukhtar and J.M. Fleureau, "Long-Term Stability Characteristics of a Lime-Treated Plastic Soil," J. Mater. Civ. Eng. 19(4):358-366, 2007.

[8] J. James and P.K. Pandian, "Industrial Wastes as Auxiliary Additives to Cement / Lime Stabilization of Soils," Adv. Civ. Eng. 2016(Article ID 1267391):1-17, 2016, DOI:https://doi.org/10.1155/2016/1267391

[9] J.M. Hoover, R.L. Handy and D.T. Davidson, “Durability of Soil-Lime-Flyash Mixes Compacted Above Standard Proctor Density," Highw. Res. Board 193:1-11, 1958.

[10] A. Kampala, S. Horpibulsuk, N. Prongmanee and A. Chinkulkijniwat, "Influence of wet-dry cycles on compressive strength of calcium carbide residue-fly ash stabilized clay," J. Mater. Civ. Eng. 26(4):633-643, 2014, DOI: https://doi.org/10.1061/(ASCE)MT.1943-5533.0000853

[11] A.K. Sabat and R.P. Nanda, "Effect of marble dust on strength and durability of Rice husk ash stabilised expansive soil," Int. J. Civ. Struct. Eng. 1(4):939-948, 2011, DOI:10.6088/ijcser.00202010080

[12] F. Yilmaz and D. Fidan, "Effect of Wetting-Drying on the Volumetric Stability of Clayey Soil Stabilized with Lime and Perlite," Eur. J. Tech. 7(2):207-218, 2017.

[13] K. Harichane, M. Ghrici and S. Kenai, "Effect of the combination of lime and natural pozzolana on the comdurability of clayey soils," Electron. J. Geotech. Eng. 15(Bund. L):1194-1210, 2010, DOl:https://doi.org/10.1007/s12665-011-1441-x

[14] M. Malekzadeh and H. Bilsel, "Effect of polypropylene fiber on mechanical behaviour of expansive soils," Electron. J. Geotech. Eng. 17 A(Abduljauwad 1993):55-63, 2012.

[15] M. Malekzadeh and H. Bilsel, "Swell and Compressibility of Fiber Reinforced Expansive Soils," Int. J. Adv. Technol. Civ. Eng. 1(2):42-46, 2012.

[16] B.R. Phanikumar, C. Manvita and R. Patnaik, "Influence of Wetting-Drying Cycles on Heave Behaviour of FiberReinforced Expansive Soil Specimens," Proceedings of the Indian Geotechnical Conference 2011, December 15-17, Kochi, India: 505-507, 2011.

[17] P. Greeshma and M. Joseph, "Rice straw Reinforcement for Improvement in Kuttanad clay," Proceedings of the Indian Geotechnical Conference 2011, December 15-17, 449-452, 2011.

[18] J.P. Prajisha and A.R. Ajitha, "Effect of Banana Fibre Reinforcement in Lime Stabilized," Proceedings of 50th Indian Geotechnical Conference, 17th - 19th December, Pune, India, 2015.

[19] V. Anggraini, A. Asadi, N. Farzadnia, H. Jahangirian and B.B.K. Huat, "Reinforcement benefits of nanomodified coir fiber in lime-treated marine clay," J. Mater. Civ. Eng. 28(6):1-8, 2016, DOI:https://doi.org/10.1061/(ASCE)MT.1943-5533.0001516

[20] P. Sukontasukkul and P. Jamsawang, "Use of steel and polypropylene fibers to improve flexural performance of deep soil - cement column," Constr. Build. Mater. 29:201-205, 2012, DOl:https://doi.org/10.1016/j.conbuildmat.2011.10.040

[21] B. Fatahi, H. Khabbaz and B. Fatahi, "Mechanical characteristics of soft clay treated with fibre and cement," Geosynth. Int. 19(3):252262, 2012, DOI:https://doi.org/10.1680/gein.12.00012
[22] A.A.S. Correia, P.J.Venda Oliveira, J.M.N.P.C. Teles and A.M.G. Pedro, "Strength of a stabilised soil reinforced with steel fibres," Proc. Inst. Civ. Eng. Geotech. Eng. 170(GE4):312-321, 2017.

[23] A.S. Muntohar and I.A. Khasanah, "Effect of moisture on the strength of stabilized clay with lime-rice husk ash and fibre against wetting-drying cycle," Int. J. Integr. Eng. 11 (9 Special Issue):100-109, 2019.

[24] BIS, IS 2720 Methods of Test For Soils: Part 1 - Preparation of Dry Soil Sample for Various Tests, 1-10, 1983.

[25] BIS, IS 2720 Methods of Test for Soils: Part 5 Determination of Liquid and Plastic Limit, 1-16, 1985.

[26] BIS, IS 2720 Methods of Test for Soils: Part 6 Determination of Shrinkage Factors, 1-12, 1972.

[27] BIS, IS 2720 Methods of Test for Soils Part 3: Determination of Specific Gravity/Section 1 Fine Grained Soils, 1-8, 1980.

[28] BIS, IS 2720 Methods of Test for Soils: Part 4 Grain Size Analysis, 1-38, 1985.

[29] Sridharan, A. and Sivapullaiah, P.V., "Mini compaction test apparatus for fine grained soils," Geotech. Test. J. 28(3):240246, 2005, DOI: https://doi.org/10.1520/gtj12542

[30] BIS, IS 2720 Methods of Test for Soils: Part 10 - Determination of Unconfined Compressive Strength, 1-4, 1991.

[31] BIS, IS 2720 Methods of Test for Soils: Part 40 Determination of Free Swell Index of Soils, 1-5, 1977.

[32] BIS, IS 1498 Classification and Identification of Soils for General Engineering Purposes, 4-24, 1970.

[33] J.L. Eades and R.E. Grim, "A Quick Test to Determine Lime Requirements for Lime Stabilization," Highw. Res. Rec. 139:6172, 1966.

[34] ASTM, D6276 Standard Test Method for Using pH to Estimate the Soil-Lime Proportion Requirement, 14:1-4, 2006.

[35] BIS, IS 4332 Methods of Test for Stabilized Soils: Part 3 Test for Determination of Moisture Density Relations for Stabilized Soil Mixtures, 1-12, 1967.

[36] J. James and P.K. Pandian, "Effect of Phosphogypsum on Strength of Lime Stabilized Expansive Soil," Gradevinar 66(12):11091116, 2014, DOI: https://doi.org/10.14256/jce.1097.2014

[37] H. Jiang, Y. Cai and J. Liu, "Engineering Properties of Soils Reinforced by Short Discrete Polypropylene Fiber," J. Mater. Civ. Eng. 22(12):1315-1322, 2010, DOI: https://doi.org/10.1061/(asce)mt.1943-5533.0000129

[38] BIS, IS 4332 Methods of Test for Stabilized Soils: Part 5 Determination of Unconfined Compressive Strength of Stabilized Soils, 1-22, 1970.

[39] H. Hasan, H. Khabbaz and B. Fatahi, "Strength Property of Expansive Soils Treated with Bagasse Ash," in: Hoyos, L. R. and McCartney, J., eds., Advances in Characterization and Analysis of Expansive Soils and Rocks, Sustainable Civil Infrastructures, Springer International Publishing, ISBN 978-3-319-61930-9: 2435, 2017, DOI: https://doi.org/10.1007/978-3-319-61931-6_3

[40] A.S. Muntohar, A. Widianti, E. Hartono and W. Diana, "Engineering Properties of Silty Soil Stabilized with Lime and Rice Husk Ash and Reinforced with Waste Plastic Fiber," J. Mater. Civ. Eng. 25(9):1260-1270, 2013, DOI: https://doi.org/10.1061/(asce)mt.1943-5533.0000659 


\title{
¡†TECI\&NE
}

Revista ITECKNE - Universidad Santo Tomás, Seccional de Bucaramanga, Colombia, Vol. 18 № 1 enero - junio de 2021

\section{Arquitectura M2M para el monitoreo ambiental en tiempo real}

\author{
M2M Architecture for environmental monitoring in real time
}

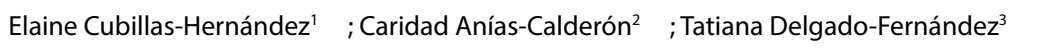

\author{
'Technological University of Havana (CUJAE), Cuba; ela90ch@gmail.com \\ ${ }^{2}$ Technological University of Havana (CUJAE), Cuba; cacha@tesla.cujae.edu.cu \\ 3̋nversidad Tecnológica de La Habana, Unión de Informáticos de Cuba, Cuba; tatiana.delgado@uic.cu
}

Recibido: 27 de agosto de 2020. Aceptado: 23 de noviembre de 2020

Resumen- En el Instituto de Geografía Tropical (IGT), y en el resto de los centros que desarrollan el Sistema de Información Ambiental del país, no se obtienen en tiempo real las mediciones ambientales. Esto se debe a que la tecnología utilizada para la comunicación de dicha información, desde los sensores que la capturan al centro donde se procesa, se encuentra obsoleta. EI objetivo de este trabajo es dar solución a la problemática antes planteada, empleando la comunicación Máquina a Máquina (M2M) como parte de la tecnología del Internet de las Cosas (IoT). Para lograr lo anterior se revisó la arquitectura M2M definida por Instituto Europeo de Normas de Telecomunicaciones $y$, a partir de ella, se precisó la que se debía emplear en la obtención de datos ambientales en tiempo real. Se seleccionó un área geográfica con características especiales, ubicada en una zona de premontaña de difícil acceso en las afueras del municipio Consolación del Sur, provincia Pinar del Río de Cuba, donde en la actualidad se monitorizan factores ambientales de interés para el país empleando métodos rudimentarios. En el área $\mathrm{M} 2 \mathrm{M}$ de dicho escenario se analizaron varias alternativas para la obtención de los datos, lo que permitió seleccionar la más adecuada, que es la que se explica en este trabajo.

Palabras clave- M2M; loT; redes de sensores ambientales; arquitectura.

Abstract- In the Institute of Tropical Geography (IGT), and in the rest of the centers that develop the Environmental Information System of the country, environmental measurements are not obtained in realtime. This is because the technology used to communicate this information, from the sensors that capture it to the center where it is processed, is obsolete. The objective of this work is to provide a solution to the problems raised above using Machine to Machine communication (M2M), as part of the Internet of Things (IoT) technology. To achieve the above, the M2M architecture defined by the European Telecommunications Standards Institute was revised and, based on it, the one that should be used to obtain environmental data in real-time was specified. Then, a geographical area with special characteristics was selected, located in a difficult-to-access premountain zone on the outskirts of the Consolación del Sur municipality, in the Pinar del Río province of Cuba, where environmental factors of interest for the country are currently monitored using archaic methods. In the $\mathrm{M} 2 \mathrm{M}$ area of this scenario, several alternatives were analyzed to obtain the data, which allowed selecting the most appropriate one, which is the one explained in this work.

Keywords- M2M; loT; networks of environmental sensors; architecture.

\section{INTRODUCCIÓN}

Las tecnologías que soportan el paradigma de Internet de las Cosas (IoT) se tornan cada vez más importantes a medida que se incrementa la necesidad de mejorar la comprensión de nuestro entorno y de convertirlo en inteligente.

Las redes de sensores inalámbricos (WSN) deben ser capaces de organizar cientos o incluso miles de nodos y proporcionar una comunicación confiable, por lo que es-

Citar este artículo como: Cubillas-Hernández E, Anías-Calderón C, y Delgado-Fernández T. Arquitectura M2M para el monitoreo ambiental en tiempo real. ITECKNE, 18(1), 2021 pp. 18 - 25. DOI: https://doi.org/10.15332/iteckne.v18i1.2531 
tos nodos deben tener las características de alta confiabilidad, baja potencia, bajo costo, facilidad de instalación y mantenimiento [1]. Las redes máquina-a-máquina (M2M) que permiten que máquinas, sensores y controladores para comunicarse entre sí sean muy similares a LAN o WAN, por eso a menudo se les denomina Internet de las cosas (IoT).

Una red M2M consiste de una gran cantidad de nodos $\mathrm{M} 2 \mathrm{M}$ y un gateway que forman un área de dominio M2M. Cada nodo M2M es un dispositivo muy flexible e inteligente equipado con algunas tecnologías de detección específicas y puerta de enlace $\mathrm{M} 2 \mathrm{M}$ que es responsable de conectar el dominio de área $\mathrm{M} 2 \mathrm{M}$ con el dominio de red [2]. En la comunicación de máquina a máquina, los dispositivos se comunican sin o casi sin intervención humana. Tareas como vigilancia remota, salud y monitoreo ambiental, redes inteligentes, ciudades inteligentes [3], hogar y la seguridad del tráfico y el transporte inteligente son ejemplos bien conocidos de comunicaciones M2M [1].

Las aplicaciones ambientales que emplean tecnología M2M suelen ser inteligentes, propiciando la detección de incendios forestales, contaminación del aire, terremotos y deslizamientos de tierra. Este tipo de aplicaciones facilitan el monitoreo de agua potable, el descubrimiento de productos químicos que contaminan los ríos y el mar y la detección temprana del desbordamiento de los ríos. También se emplean en la agricultura inteligente para, por ejemplo, mejorar la calidad de los vinos y los cultivos y controlar las condiciones de microclima en las casas verdes.

En los centros de información ambiental en Cuba existen cada vez mejores condiciones tecnológicas para el monitoreo ambiental; sin embargo, aún no se completa la medición en tiempo real de sus observaciones en todas las estaciones dispersas a lo largo del país, o la tecnología utilizada para la comunicación de los datos, desde los sensores que los capturan al centro donde se procesa, se encuentra obsoleta.

Debido a la problemática existente en los centros de monitoreo ambiental, en nuestro país, se decidió explorar la implementación de un sistema loT para obtener en tiempo real las mediciones ambientales. En este trabajo se presenta una arquitectura M2M para monitorear los datos ambientales en tiempo real, la cual debe también beneficiar la coordinación entre centros de monitoreo, al habilitar la capacidad de anticiparse ante cualquier variable climática o agrícola.

\section{Sistemas M2M}

Los sistemas M2M constituyen una sub-área de loT que juega un importante papel en su implementación [4]. El número de dispositivos conectados M2M alcanzarán los 13 mil millones en 2021, el 51\% estarán conectados directamente a Internet [5].

M2M se centra en la conectividad y se refiere a sistemas autónomos o controlados por humanos, que involucran dispositivos que automáticamente recopilan datos (temperatu- ra, humedad, velocidad, sitio, biológicos, señales, etc.), intercambian información e interactúan con el medio ambiente según la necesidad y sin intervención del hombre [5]. Un dispositivo en un sistema M2M no solo recopila datos para su propio uso, también comparte los datos con otros dispositivos automáticamente para lograr ciertos objetivos [4].

Este paradigma de comunicación facilita las comunicaciones ubicuas con un gran número de dispositivos inteligentes conectados por enlaces alámbricos / inalámbricos, que interactúan entre sí sin intervención humana directa. Las aplicaciones basadas en comunicación M2M están ampliamente difundidas en escenarios como redes inteligentes, e-sanidad, redes de área doméstica, transporte inteligente, sistemas de gestión ambiental, monitoreo ambiental, ciudades inteligentes y automatización industrial, entre otros [6].

Para seleccionar las tecnologías apropiadas para la gestión de acceso y durante el diseño del protocolo, se deben considerar las características únicas y los requerimientos generales de M2M [7]. Por ejemplo, Wi-Fi tiene un rango de acceso de $100 \mathrm{~m}$ en Wireless Local Areas Networks (WLANs), lo cual es bastante corto para atender MTCD densamente desplegados en grandes ambientes al aire libre. Así, IEEE 802.11ah (Wi-Fi HaLoW) considerando diversos requisitos de calidad del servicio (QoS), se puede integrar en productos $\mathrm{Wi}-\mathrm{Fi}$, ya que puede ser configurado de forma flexible para diferentes aplicaciones. IEEE 802.11 es una de las tecnologías inalámbricas que se está modificando para su uso en loT debido a su implementación de amplio rango y soporte para conectividad IP. Por lo tanto, es un protocolo prometedor para la implementación de M2M a gran escala de bajo costo y eficiencia energética. De acuerdo con Amudo \& Othman [7], algunas características asociadas con la gestión de acceso en tecnologías M2M específicas son las siguientes:

- Wi-Fi: es posible que Wi-Fi no satisfaga completamente los diversos requisitos de QoS para MTC, debiendo modificarse para adaptarse a diferentes casos de uso.

- IEEE 802.11: las soluciones personalizadas para IEEE 802.11 pueden ser diseñadas para atender a diversas aplicaciones de MTCD.

- ZigBee: las redes Mesh ZigBee se caracterizan por una baja utilización, ya que no tienen balizas. Las topologías basadas en árboles también tienen limitaciones que se manifiestan en una menor eficiencia de transmisión y una estrecha sincronización.

- Bluetooth: tiene problemas de gestión de energía, así como de agrupación de terminales y agregación de datos cuando los terminales M2M deben conectarse en una piconet (dispositivos de red que se conectan a través de Bluetooth). Sin embargo, puede ser empleado eficazmente en domótica [8].

En relación con las arquitecturas M2M, Chen \& Lien [9] abogan por un modelo de referencia de arquitectura M2M para facilitar la colaboración durante la implementación práctica y operación entre subsistemas y entre hardware y 
software. Las comunicaciones M2M admiten información autónoma (incluyendo datos y control) transporte dentro de todo el sistemas loT basados en la nube o sistemas ciberfísicos. Por tanto, el modelo de referencia de comunicación M2M que proponen los autores referidos proveerá transparencia al software de aplicación y escalabilidad de hardware.

Cuerpos de estándares a nivel global y regional han sistematizado modelos de referencia de arquitectura loT. Por ejemplo, el Instituto Europeo de Normas de Telecomunicaciones (ETSI), junto con oneM2M han desarrollado estándares para M2M [6]. En acápites posteriores se profundiza en la arquitectura M2M de ETSI.

Entre los trabajos relacionados estudiados que implementan arquitecturas M2M se encuentra la propuesta de Datta et al. [10] que plantea una arquitectura loT que permite la interacción en tiempo real entre clientes móviles y cosas inteligentes (sensores y actuadores) a través de un gateway inalámbrico. En [11] se propone una solución basada en loT para detección de gases ambientales que preceden a un enfoque plug and play, cuya interfaz se define utilizando el protocolo receptor/transmisor asíncrono universal. La comunicación inalámbrica se realiza a través de los estándares IEEE 802.15.4 y IEEE 802.11 (Wi-Fi). El sensor propuesto en ese artículo detecta humo, oxígeno, hidrógeno, monóxido de carbono, vapor de alcohol, petróleo licuado, gas, benceno, amoníaco, metano y propano. Mientras en [12] se centran en el desarrollo de una arquitectura M2M para aplicaciones domésticas e industriales. Específicamente, para seguimiento ambiental implementado con tecnología WebSocket y ZigBee, donde la red de sensores ZigBee se utiliza para recoger datos de temperatura y humedad. Una implementación de sistema loT para la medición de calidad del aire es descrita en [13]. Se monitorean, en este estudio, la temperatura, humedad, presión atmosférica, densidad de polvo y concentraciones de monóxido y dióxido de carbono, metano y óxidos de nitrógeno. Se basa en tecnologías de código abierto de software y hardware.

La principal contribución del presente artículo radica en la arquitectura $M 2 M$, propuesta que, con el empleo de buenas prácticas de tecnologías $\mathrm{M} 2 \mathrm{M}$, es implementada a la medida de un caso real en una granja agrícola ubicada en una zona pre-montaña de difícil acceso en las afueras del municipio Consolación del Sur, provincia Pinar del Río, en Cuba, donde anteriormente se monitorizaban factores ambientales empleando métodos rudimentarios, desconectados del centro de análisis de la provincia. Con la solución propuesta, se habilita el monitoreo ambiental desde un centro regional, con lo cual se logra analizar los datos en tiempo real y hacer más efectivas las decisiones en el marco del Sistema de Información Ambiental en Cuba.

\section{METODOLOGÍA}

El modelo de alto nivel de arquitectura funcional ETSI propuesto en la especificación "TS 102690" [14] consiste en un dominio de red y dominio de dispositivo y puerta de enlace, como se refleja en la Fig. 1.

Fig. 1. DOMINIOS DE LA ARQUITECTURA FUNCIONAL M2M DE ETSI [14]

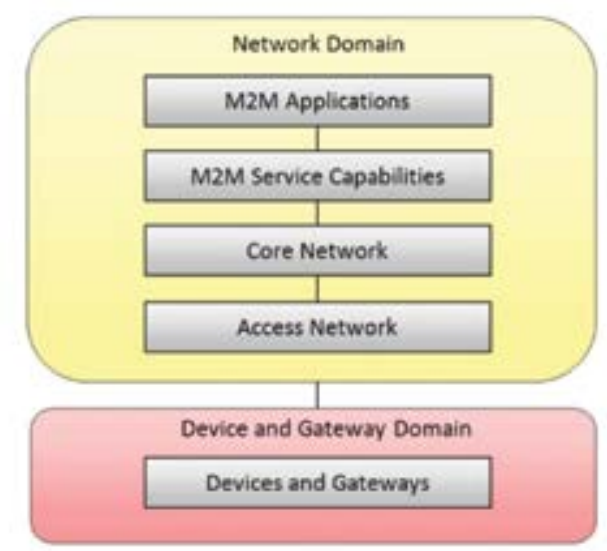

Fuente: Los autores.

Para aplicar la comunicación M2M a la monitorización ambiental en tiempo real del Sistema Nacional de Información Ambiental, se revisó la arquitectura de referencia M2M definida por la ETSI [14], la cual se muestra en la Fig. 2, lo que constituye el punto de partida metodológico.

Los elementos que se destacan en dicha arquitectura son:

- Dispositivo M2M (Sensor): Módulo que se encuentra en una máquina remota y que provee comunicación con el servidor. Usualmente, el dispositivo M2M también tiene capacidad de proceso pudiendo ejecutar la aplicación de negocio. Debe implementar un protocolo para poder comunicarse con la máquina donde se encuentra, y otro de comunicación, para el envío de información.

- Red de acceso: Puede ser de fija o inalámbrica. Permite la conectividad entre el dispositivo M2M y el gateway. Emplea diversas tecnologías: PLC (por las siglas del término en inglés Power Line Communication), Ethernet, RDSI (Red Digital Servicios Integrados), ADSL (por las siglas del término en inglés Asincronyc Digital Suscriber Line), GSM (por las siglas del término en inglés Global System for Mobile Communications), UMTS (por las siglas del término en inglés Universal Mobile Telecommunications System), HSDPA (por las siglas del término en inglés High Speed Digital Packet Access), WiFi, Bluetooth, RFID, ZigBee, UWB.

- M2M Gateway: Actúa como intermediario entre la red de acceso y la red de núcleo y provee intercomunicación e interacción entre los dispositivos M2M y entre estos y las aplicaciones. Puede ser configurado para encargarse del direccionamiento y la gestión de los dispositivos M2M. 
- Red de núcleo (Core network) M2M: Es la red encargada de unir y transportar la información desde los gateways a las aplicaciones.

- Aplicaciones M2M: Las aplicaciones M2M se encargan de realizar el análisis de los datos, procesarlos y hacerlos entendibles por los seres humanos, tanto en forma de tabla como de gráfico, según el tipo de aplicación y sus funcionalidades, las que son especificadas por los desarrolladores. Pueden estar vinculadas con la gestión de los dispositivos. En cada implementación en particular se decide si la gestión se hace donde se encuentra la aplicación o desde otro lugar, que pudiera ser un centro intermedio.

La arquitectura de comunicación M2M que se propone para la medición ambiental se inspira en la arquitectura M2M de la ETSI [14]. Se divide en tres partes fundamentales: área M2M (zona de medición), red de comunicación y aplicación.

En el área M2M (zona de medición) se encuentran los sensores ambientales M2M que se comunican con él o los gateways, utilizando diferentes protocolos de comunicación, típicamente estándares (Ej.: Modbus y MQTT o protocolo de colas de mensajes de transporte de telemetría), que deben ser entendidos tanto por el sensor como por el gateway. En dependencia del protocolo de comunicación que se emplee entre estos dispositivos y del número de sensores que admite cada gateway, se utilizará por cada grupo de sensores uno o más gateways. En el área M2M también pueden existir nodos de sensores, formando parte de la red de sensores ambientales. Los nodos de sensores son dispositivos a los cuales se les puede conectar otros sensores no M2M, brindando la posibilidad de convertir su comunicación a M2M.

Los gateways M2M permiten la interconexión entre la red de sensores y la red de comunicación. En el área M2M pueden existir uno o varios gateways dependiendo del número y tecnología de sensores que se vayan a emplear. La mayoría de las pasarelas que se utilizan en el área M2M son dispositivos diseñados específicamente para aplicaciones M2M con capacidades de almacenamiento, en memoria RAM integrada, de los mensajes que transmiten los sensores, y con soporte de varias decenas de estos conectados al mismo tiempo. Los gateways pueden conectar sensores o nodos de sensores empleando puerto USB o puerto serie.

Entre los sensores y el gateway existe una red de pequeño alcance, la cual constituye la red M2M. En esta se utilizan típicamente los estándares de comunicación WiFi, ZigBee, GSM, GPRS y Bluetooth, aunque pudieran emplearse otros teniendo en cuenta, principalmente, las especificaciones de los dispositivos M2M.

Fig. 2. ELEMENTOS DE LA ARQUITECTURA M2M DE REFERENCIA [14]

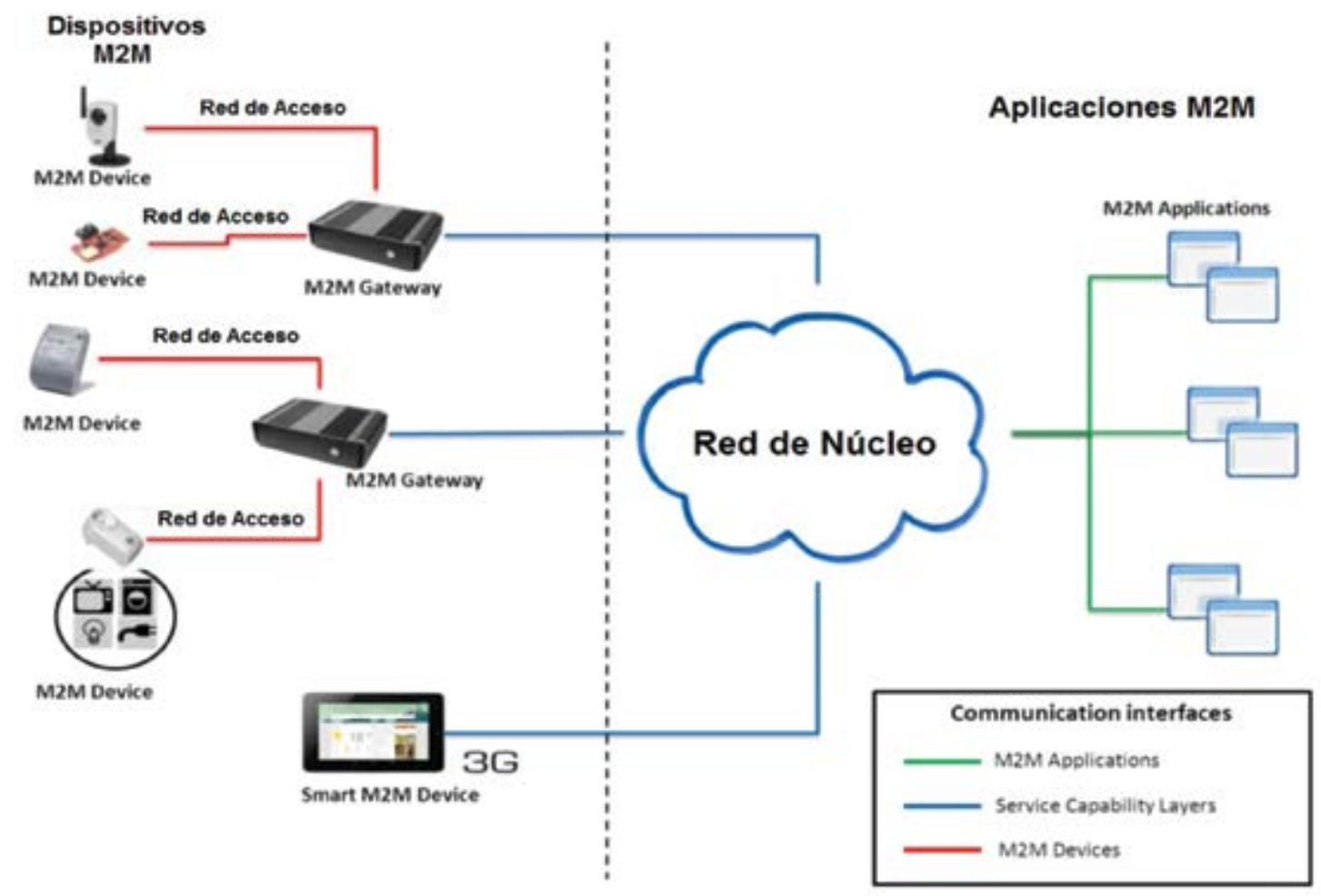

Fuente: Los autores. 
Los datos obtenidos en el área M2M son enviados desde el gateway a las aplicaciones finales que los procesan a través de la red de comunicaciones, la cual emplea diferentes tecnologías de acceso sobre la que típicamente se soporta el protocolo IP.

Como caso de estudio, se seleccionó un área geográfica con características especiales, ubicada en una zona pre-montaña de difícil acceso en las afueras del municipio Consolación del Sur, Pinar del Río, donde en la actualidad se obtienen parámetros ambientales de interés. Una vez establecido el escenario a utilizar se analizó cómo lograr la obtención y transmisión de los datos a la aplicación final, de manera que los mismos se puedan leer en tiempo real.

A continuación, partiendo de la arquitectura de referencia, se analizaron varias alternativas para el área M2M de dicho escenario, escogiéndose la que se explica en este trabajo, que es la mejor solución a la situación existente y que, a la vez, se ajusta al presupuesto con que se cuenta para la implementación de la comunicación M2M en el sistema de información ambiental.

Finalmente, los datos obtenidos se deben transmitir en tiempo real a una aplicación final, situada en un centro de monitoreo ambiental, que los debe procesar.

\section{RESULTADOS}

Para el empleo de la tecnología M2M en el monitoreo ambiental en tiempo real, se parte de lo que en la actualidad se realiza para la obtención de los datos ambientales en un área geográfica. La misma está ubicada en una premontaña en las afueras del municipio Consolación del Sur, provincia de Pinar del Río, específicamente en una finca llamada "Cascajales". Que se encuentra a una distancia apro- ximadamente de 40 kilómetros del centro meteorológico de Pinar del Río.

En esta ubicación geográfica y en la mayoría de las zonas de monitoreo importantes para el país, no es posible obtener los datos ambientales en tiempo real, debido a que es necesaria la presencia de personas para la obtención y transmisión de los datos dado que:

- La estación de monitoreo no tiene posibilidad de enviar los datos de manera automática a medida que los obtiene.

- No se utiliza una red de comunicación desde donde se miden los datos hasta el centro meteorológico provincial.

La figura 3 ilustra la situación de monitoreo en el caso de estudio antes de proponer la solución M2M.

En función del objetivo planteado y para resolver la problemática existente, se decidió proponer la tecnología M2M para la obtención de datos ambientales en tiempo real. Se analizaron varias alternativas para el área M2M de la arquitectura propuesta (Fig. 3) en las que fue necesario tener en cuenta:

- Los indicadores ambientales que exige el Sistema de Información Ambiental (temperatura y humedad del suelo, punto de rocío, velocidad del viento, temperatura del ambiente, humedad relativa, presión atmosférica, calidad del aire y cantidad de lluvia), así como de otros recomendables para la ampliación de este tipo de mediciones.

- Los dispositivos M2M ambientales que proveen varios fabricantes.

Fig. 3. MONITOREO DE DATOS AMBIENTALES ANTES DE LA SOLUCIÓN M2M

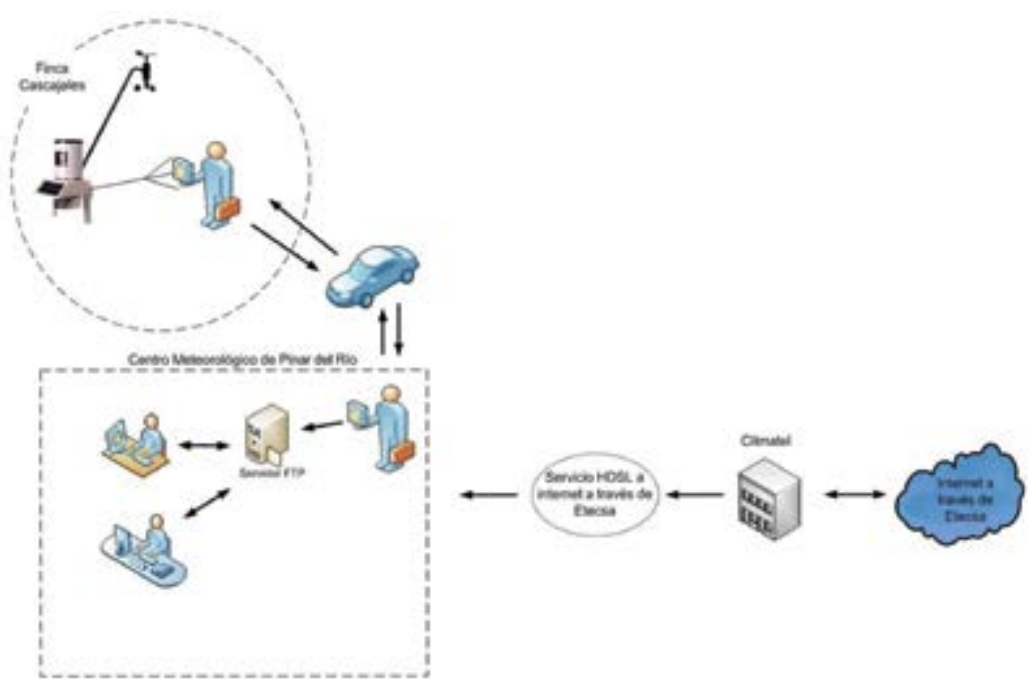

Fuente: Los autores. 
Finalmente, se escogió la alternativa que mejor soluciona la situación existente y que, a la vez, se ajusta al presupuesto con que se cuenta para la implementación de la comunicación M2M en el sistema de información ambiental. En esta alternativa la red de sensores ambientales está compuesta por dispositivos de los fabricantes Libelium y Eurotech. Se escogió para la misma el nodo de sensores integrado de Libelium, Fig. 4; llamado Waspmote Plug \& Sense! [15], pero solo empleando la placa de agricultura, y el sensor ReliaSENS 18-12 [16] de la alternativa del fabricante Eurotech, Fig.4. Ambos dispositivos admiten comunicación WiFi y GPRS hacia el gateway.

\section{Fig. 4. DISPOSITIVOS IOT SELECCIONADOS EN LA SOLUCIÓN PROPUESTA. 3-a WASPMOTE PLUG \& SENSE [15] (IZQUIERDA); RELIASENS 18-12 [16]} (DERECHA)

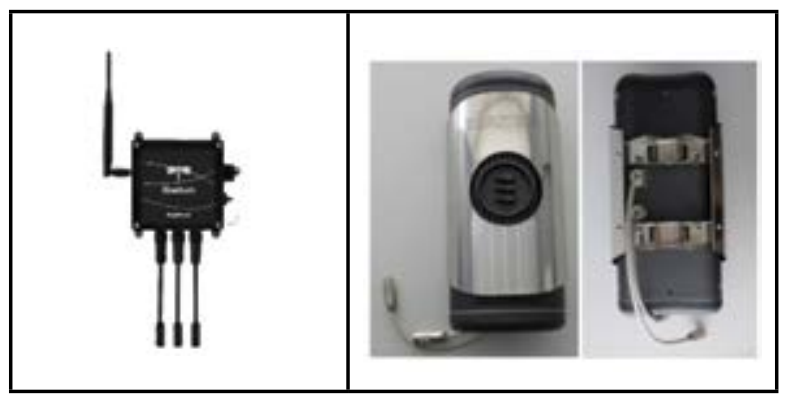

Fuente: Los autores. .

Adicionalmente, se plantea considerar, para la estación agrometeorológica que se encuentra actualmente instalada en la zona de interés, el nodo de sensores estandarizado SN802GR420-4 del fabricante Murata [17] que posibilita la conversión de los datos de dicha estación a la tecnología M2M. Para esto es necesario conectar el puerto serie RS232 de la estación agrometeorológica al puerto serie RS232 que posee el nodo de sensor. De esta forma, el nodo de sensor actúa como un intermediario entre la estación y el gateway posibilitando la comunicación entre estos dos elementos en el área M2M.

El nodo de sensores por el que se optó para la estación agrometeorológica, además del puerto serie RS-232, tiene conexión WiFi y admite los estándares $802.11 \mathrm{~b} / \mathrm{g} / \mathrm{n}$. La batería interna que posee puede, como promedio, superar los cinco años de uso, y al agotarse lo que requiere son tres baterías de tipo $A A$, que son fáciles de obtener no siendo muy costoso.

En esta solución, los dispositivos M2M seleccionados se puedan conectar de dos maneras:

1. Utilizando un solo gateway que conecte todos los dispositivos mediante WiFi, que es la tecnología de conexión que admite tanto el nodo de sensores SN802GR420-4, como el Waspmote Plug \& Sense y el ReliaSENS 18-12.
2. Utilizando dos gateway: uno para comunicar, mediante la tecnología celular GPRS, el Waspmote Plug \& Sense! y el ReliaSENS 18-12 y, el otro, para conectar el nodo de sensores SN802GR420-4 vía WiFi.

De estas dos posibilidades se escoge la primera ya que es más económica. El gateway seleccionado es el ReliaGATE 50-21 [18] que tiene variedad de estándares de conexión, los cuales pudieran ser necesarios posteriormente para ampliar la red de sensores en la zona de la premontaña. Además, dicho gateway está específicamente diseñado para el transporte de datos con el protocolo MQTT que es el protocolo M2M que se ha seleccionado para la implementación de la comunicación M2M.

Esta alternativa, además, considera, para la gestión de los dispositivos, el software de gestión de Eurotech ESF [19], el cual da la posibilidad de mostrar los datos de los sensores en tiempo real y exportarlos al formato MS Excel para ser colocados en un servidor FTP. Se recomienda que dicha gestión y servidor se encuentren en el Centro Meteorológico de Pinar del Río.

Esta solución, que permite la obtención de los datos ambientales empleando la tecnología M2M, puede adaptarse a diferentes aplicaciones, de manera que es fácil su expansión a otros proyectos del territorio nacional, específicamente a lugares donde se requiera la monitorización ambiental. La Fig. 5 muestra la arquitectura M2M propuesta.

\section{Fig. 5. ARQUITECTURA M2M EN ESTACIÓN DE MONITOREO AMBIENTAL}

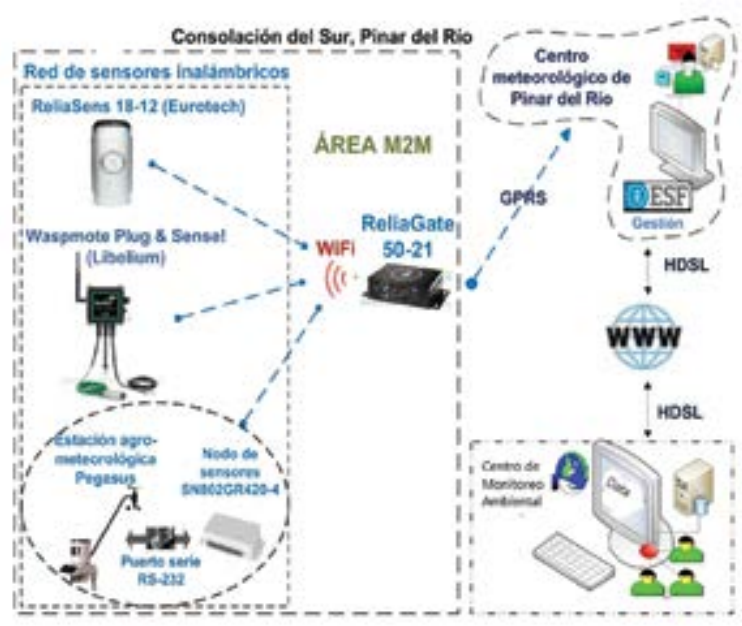

Fuente: Los autores.

El descubrimiento de sensores se inicia estableciendo una conexión de los dispositivos M2M con el gateway (ReliaGate 50-21). Esta fase es necesaria debido a que los dispositivos y terminales M2M se pueden agregar o eliminar en tiempo real. Para esta fase de descubrimiento se ofrece 
una API en el Gateway; una vez descubiertos, los sensores pueden ser elegidos por el usuario para recibir las observaciones codificadas en el Lenguaje de Etiquetado de Sensores SenML (Sensor Markup Language) que está implementado en JSON. Con ello se habilita la posibilidad de que el servidor analice eficientemente un gran número de metadatos del sensor en un período de tiempo muy corto.

La arquitectura propuesta se aplicó de forma experimental en una estación de monitoreo ubicada en la Finca Cascajales del municipio Consolación del Sur en la provincia Pinar del Río.

Se emplea, para este ejemplo, la Mapoteca Digital del Instituto de Geografía Tropical, soportada en la plataforma OpenGeo Suite [20], para mostrar en el mapa la zona de medición y los valores medidos desde los sensores ubicados en la finca y sus alrededores. Una muestra se puede ilustrar en la Fig. 6.

Fig. 6. APLICACIÓN CLIENTE DE MONITOREO DE VARIABLES AMBIENTALES BASADA EN LA ARQUITECTURA M2M

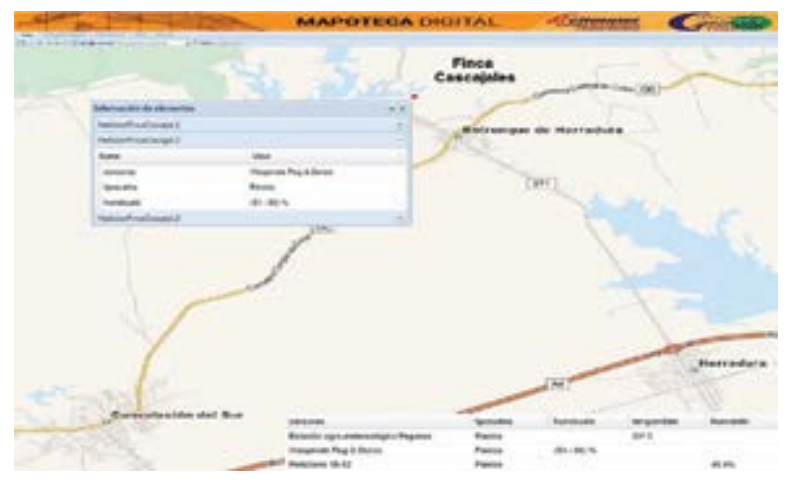

Fuente: Los autores.

\section{CONCLUSIONES}

La comunicación M2M y su incorporación en los sensores ambientales permite actualizar las tecnologías de monitorización existentes, y crear una red inteligente y eficiente para la transmisión de datos en tiempo real.

En este trabajo se definió una arquitectura para el empleo de la tecnología M2M en el monitoreo ambiental en tiempo real. Además, en el mismo se explica, entre varias alternativas analizadas, la que mejor resuelve el monitoreo ambiental en tiempo real en un área geográfica de interés para la Agencia de Medio Ambiente y al Instituto de Geografía Tropical.

Mientras la solución que se propone tiene la posibilidad de ser expandida a otros proyectos del territorio nacional, el equipo de trabajo se encuentra laborando en otras tareas de investigación complementarias que deben tener su fruto en un futuro cercano. Entre estas investigaciones, cabe mencionar las siguientes:
- El desarrollo de un gateway para redes de sensores inalámbricos, basado en plataforma Raspberry Pi, y la evaluación de su desempeño respecto a la propuesta de arquitectura aquí presentada.

- La orquestación de nodos niebla entre la nube y los dispositivos loT usando FogFlow y la plataforma loT FIWARE como middleware.

\section{AGRADECIMIENTOS}

Este artículo se desarrolló en el marco del proyecto InfoGeo: Sistema de Información Ambiental en Cuba, coordinado por el Instituto de Geografía Tropical.

\section{REFERENCIAS}

[1] K.-L. Huang, L.-H. Yen, J.-T. Wang et. al., «A BackboneAware Topology Formation (BATF) Scheme for ZigBee Wireless Sensor Networks,"Wireless personal communications, vol. 68, n० 1, pp. 47-64, 2013, DOI:https://doi.org/10.1007/s11277-011-0438-9

[2] D. Niyato, L. Xiao y P. Wang, «Machine-to-machine communications for home energy management system in smart grid,» IEEE Commun. Mag., vol. 49, n 4, pp. 53-59, 2011, DOI: https://doi.org/10.1109/MCOM.2011.5741146

[3] M. S. H. Ansari y M. Mehrotra, "Securing M2M communication in Smart Cities," de International Conference for Emerging Technology (INCET), 2020, june. DOI: https://doi.org/10.1109/INCET49848.2020.9154158

[4] Y. Cao, T. Jiang y Z. Han, "A survey of emerging M2M systems: Context, task, and objective," IEEE Internet of Things Journal, vol. 3, no 6, pp. 1246-1258, 2016, DOI: https://doi.org/10.1109/JIOT.2016.2582540

[5] S. D. Castilho, E. P. Godoy y F. Salmen, «Implementing Security and Trust in loT/M2M using Middlewarepp,» de International Conference on Information Networking (ICOIN), 2020, DOI: https://doi.org/10.1109/ICOIN48656.2020.9016435

[6] P. K. Verma, R. Verma, A. Prakash, A. Agrawal, K. T. R. Naik, T. Khalifa, M. Alsabaan, T. Abdelkader y A. Abogharaf, «Machineto-Machine (M2M) communications: A survey,» Journal of Network and Computer Applications, vol. 66, pp. 83-105, 2016, DOI: https://doi.org/10.1016/j.jnca.2016.02.016

[7] O. A. Amodu y M. Othman, «Machine-toMachine Communication: An Overview of Opportunities," Computer Networks, 2018 , DOI: https://doi.org/10.1016/j.comnet.2018.09.001

[8] N. Xia, H. Chen y C. Yang, «Radio resource management in machine-to-machine communications-A survey,» IEEE Communications Surveys \& Tutorials, vol. 20, no 1, pp. 791-828, 2017, DOI: https://doi.org/10.1109/COMST.2017.2765344

[9] K. Chen y S. Lien, «Machine-to-machine communications: Technologies and challenges,» Ad Hoc Networks, vol. 18, pp. 3-23, 2014, DOl:https://doi.org/10.1016/j.adhoc.2013.03.007

[10] S. K. Datta, C. Bonnet y N. Nikaein, «An IoT gateway centric architecture to provide novel M2M services.," de 2014 IEEE World Forum on Internet of Things (WF-IoT), 2014, DOI: https://doi.org/10.1109/WF-loT.2014.6803221 
[11] J. B. Gomes, J. J. Rodrigues, R. A. Rabêlo, S. Tanwar, J. Al-Muhtadi y S. Kozlov, «A novel Internet of things-based plug-and-play multigas sensor for environmental monitoring,» Transactions on Emerging Telecommunications Technologies, vol. e3967, pp. 1-11, 2020, DOl:https://doi.org/10.1002/ett.3967

[12] K. Shuang, X. Shan, Sheng, Z. y C. Zhu, «An efficient ZigBee-WebSocket based M2M environmental monitoring system," de 2014 IEEE 12th International Conference on Dependable, Autonomic and Secure Computing, 2014, DOI: https://doi.org/10.1109/DASC.2014.64

[13] A. Ochoa, L. Cangrejo y T. Delgado, «Alternativa Open Source en la implementación de un sistema loT para la medición de la calidad del aire,» Revista Cubana de Ciencias Informáticas, vol. 12, no 1, pp. 189-204, 2018.

[14] ETSI, «Machine-to-Machine communication (M2M): Functional architecture», Technical Specification ETSI TDS 102 690 V1.2.1, 2013, https://www.etsi.org/deliver/etsi_ts/102600 _102699/102690/02.01.01_60/ts_102690v020101p.pdf
[15] Libelium, «Plug \& Sense! Technical guidej», Development website. https://development.libelium.com/plug-and-sensetechnical-guide/. 2019.

[16] Eurotech, "ReliaSENS 18-12-01 Cloud-connected Environment Monitoring System», User Manual. RESENS-18-12-01_UsrMan_EN_1.0. 2014, file:///C:/Users/ arturo/Downloads/RESENS-18-12-01_UsrMan_EN_1.0.pdf

[17] Murata, «SN802GR420-4», Innovation in electronics. 2018, https://wireless.murata.com/datasheet?/RFM/data/ sn802gr420-4.pdf

[18] Eurotech, «ReliaGATE 50-21- Especifications», Multi-Service Gateway \& Edge Controller. 2014, https://www.eurotech.com/ DLA/datasheets/Products_Eurotech/ReliaGATE50-21_sf.pdf

[19] Eurotech, "loT Edge Framework» Everyware Software Framework Developer's Hub. 2020, https://esf.eurotech.com/docs

[20] Geoicon, «OpenGeo Suite» 2020, http://www.geoicon.com/ products/third-party-products/opengeosuite 